\title{
Pelo letramento ameaçado
}

\author{
Luiz Carlos de Assis Rocha
}

UFMG

\section{Abstract}

The Brazilian teacher who cares about the teaching of his or her mother tong will certanly have wondered about the main reasons and objectives for the teaching of Portuguese and about what to do to reach these objectives. This paper will thus discuss two main points of view: $\mathrm{a}$ - the main reason of the school is to teach standard Portuguese; $\mathrm{b}$ - standard Portuguese should be tought without emphasis on Grammar. After having discussed these topics in a more theoretical way, the author goes into the classroom, presenting practical and objetive proposals for the teaching of standard Portuguese without emphasis on Grammar. 
I dalena formou-se no ano passado em Letras/Português, em uma faculdade do interior de Minas Gerais. No início deste ano, a convite do prefeito de sua cidade, a jovem recém-formada viuse de repente diante de quatro turmas de $5^{\underline{a}}$ e $6^{\underline{a}}$ séries, com a finalidade de ensinar Língua Pátria, "a matéria mais difícil e importante da Escola", como fez questão de frisar a Diretora. A personagem é fictícia, mas a situação aqui apresentada repete-se com freqüência nas escolas brasileiras.

Apesar de muito jovem, Idalena não se limita a repetir o que está no livro didático adotado pela Escola. Da mesma forma, não obedece rigidamente ao programa estabelecido pela Coordenação, que, por sua vez, segue as diretrizes traçadas pela Secretaria de Estado da Educação. Para Idalena, o mais importante é o "eppur, si muove", de Galileu, e o "je pense, donc je suis", de Descartes, que não param de martelar a sua cabeça neste começo de vida profissional. $\mathrm{Na}$ verdade, o que interessa à jovem professora é aquela palavrinha mágica que ouvira uma vez de um professor da Faculdade de Letras: convicção. Podem os programas, as diretrizes, os currículos e os parâmetros estabelecer isto ou aquilo, mas o importante é que, segundo Idalena, "eu me convença de que a verdade, o caminho, a postura é esta, não aquela”. A jovem professora perseguiu essa "filosofia", digamos assim, durante todo o seu curso superior, mas, segundo ela mesma, os professores dos cursos de Letras estão pouco preocupados com o que se passa em uma sala de aula.

Essa convicção a respeito do ensino de Português passou a ter, na cabeça de Idalena, contornos mais seguros, a partir de um fato muito simples. No primeiro dia de aula, ao chegar à Escola, depois de transpor o portão principal, a jovem professora, intuitivamente, 
parou um instante, ao receber o primeiro jorro da gritaria dos alunos no pátio. Parou, olhou para a criançada, pensou e, do mais profundo do seu ser, surgiu a pergunta: "O que posso eu fazer, como professora de Português, para que esses meninos sejam cidadãos capazes, competentes e que, além de serem indivíduos verdadeiramente pensantes, sejam de fato inseridos na sociedade em que vivemos, usufruindo de todos os seus bens materiais e espirituais?"

Nas linhas que se seguem, vamos, com a ajuda de Idalena, tentar responder à pergunta formulada por ela. A resposta será dividida em três partes: 1 - O objetivo primordial do ensino de Português; 2 - O ensino da língua padrão sem o estudo da gramática; 3 - A prática do ensino de Português.

As propostas apresentadas neste artigo constituem a essência do PROJETO GNM - Gramática Nunca Mais - que está sendo desenvolvido por um grupo de pesquisa na Faculdade de Letras da UFMG, sob a coordenação do autor deste artigo. As bases desse projeto foram publicadas recentemente em forma de livro, pela Editora UFMG (ROCHA, 2002).

\section{O OBJETIVO PRIMORDIAL DO ENSINO DE PORTUGUÊS}

Idalena sugeriu que a questão do objetivo primordial do ensino de Português fosse analisada tendo em vista três aspectos: o pragmático, o sócio-cultural e o lingüístico.

\subsection{O aspecto pragmático}

Para discorrer sobre esta questão, vamos pensar em duas hipóteses: 1 - O aluno termina o curso médio (ou o fundamental) e ingressa diretamente no mercado de trabalho; $2-\mathrm{O}$ aluno faz um curso superior.

$\mathrm{Na}$ primeira hipótese, o jovem ingressa no mercado de trabalho, quer como técnico, quer como um indivíduo que não tem formação específica. De qualquer forma, esse jovem entrará em contato com textos objetivos, neutros, técnicos, não com textos 
literários, com textos criados por colegas ou com textos que sejam a reprodução da língua falada. É evidente que isso pode acontecer em alguns casos específicos, como com aqueles indivíduos que se dedicam, por exemplo, a alguma forma de criação artística. É preciso lembrar, no entanto, que mesmo esses indivíduos não podem prescindir do contato constante com a língua padrão, através da leitura - e às vezes da escrita - de textos de jornais, revistas, artigos e livros técnicos ou meramente informativos, correspondência de qualquer tipo, manuais de instrução, regulamentos, pareceres, descrições, relatórios, avisos, etc. Isso é, portanto, o que acontece com a imensa maioria dos jovens brasileiros, que terminam o curso fundamental ou médio e vão trabalhar como auxiliares de escritório, balconistas, vendedores, mensageiros, secretários, recepcionistas, bancários ou como técnicos em eletrônica, construção civil, telecomunicação, instrumentação, meio-ambiente, etc.

Na segunda hipótese - no caso de um jovem ingressar em um curso superior -, quer para a leitura dos textos formais necessários à sua formação, quer para a redação de trabalhos e provas, quer ainda para o contato verbal com os colegas e professores e para a apresentação de trabalhos orais, o estudante precisará dominar a língua padrão. É evidente que, depois de formado, o profissional de qualquer especialidade será obrigado a usar a norma culta, nos relatórios, laudos, petições, requerimentos, cartas, ofícios, avisos, sites, e-mails, além de usá-la na redação de textos mais elaborados - como artigos e livros, por exemplo - e na comunicação oral.

Se estamos insistindo nesse assunto, com a repetição talvez um pouco exaustiva de situações e contextos em que se faz necessário o emprego da língua padrão, é porque queremos realçar a primazia do ensino na norma culta na escola, tendo em vista as reais necessidades que o cidadão comum vai ter vida afora, com relação ao emprego dessa modalidade de língua. Trata-se, portanto, de uma questão de ordem pragmática, utilitarista. Esta ênfase especial que estamos dando a esse assunto se faz necessária, porque há muitos professores de Português mal informados - ou mal formados - e mesmo teóricos 
do assunto, que insistem na primazia do ensino da língua artística, literária - se é que se pode "ensinar" a língua literária -, muitas vezes relegando-se a um segundo plano, ou mesmo negligenciando-se, o ensino da língua considerada padrão. Muitas vezes prioriza-se em sala de aula o estudo e até mesmo o ensino da língua falada que o aluno traz de casa, o que demonstra uma evidente confusão de objetivos: de fato, por um lado, não faz sentido estudar ou mesmo analisar em uma escola de nível secundário ou médio a língua falada coloquial do aluno. Com que objetivo isso seria feito? Não faz sentido também "ensinar" ao aluno a língua falada que ele já usa - diga-se de passagem - com muito mais desenvoltura que o professor. É claro que o professor poderá mostrar para os seus alunos textos em língua falada, com a finalidade de distinguir essa língua falada da língua escrita, mas isso não significa que ele vá estudar ou ensinar o dialeto oral que o aluno traz de casa.

Podemos dizer, em síntese, que, na própria escola e depois de sair dela, o cidadão comum vai precisar, basicamente, é da língua padrão. É indispensável que se insista nesse posicionamento, porque alguns professores mal informados, como dizíamos, com o pretexto de aplicar em sala de aula algumas teorias lingüísticas recentes (válidas por si mesmas, é verdade, mas de pouca aplicação imediata em uma sala de aula), esquecem-se de capacitar o aluno do curso fundamental ou médio a ler ou escrever uma ou duas páginas em português padrão, preferindo "estudar" com esse aluno a língua oral que ele já fala, ou mesmo restringindo-se à apreciação de obras de cunho literário. Lembremo-nos, porém, de dois autores que insistem na primazia do ensino da língua padrão na Escola. POSSENTI (1997, p. 17) é categórico com relação assunto: "Talvez deva repetir que adoto sem qualquer dúvida o princípio (quase evidente) de que o objetivo da escola é ensinar o português padrão. [ ... ] Qualquer outra hipótese é um equívoco político e pedagógico" (grifo do autor). Magda Becker Soares (SOARES, 2000, p. 1) afirma em recente artigo publicado no Jornal do Brasil ("Letrar é mais que alfabetizar"): 
“... letramento é o estado em que vive o indivíduo que não só sabe ler e escrever, mas exerce as práticas sociais de leitura e escrita que circulam na sociedade em que vive: sabe ler e lê jornais, revistas, livros; sabe ler e interpretar tabelas, quadros, formulários, sua carteira de trabalho, suas contas de água, luz, telefone; sabe escrever e escreve cartas, bilhetes, telegramas sem dificuldade, sabe preencher um formulário, sabe redigir um ofício, um requerimento. São exemplos das práticas mais comuns e cotidianas de leitura e escrita; muitas outras poderiam ser citadas."

\subsection{O aspecto sócio-cultural}

Não há dúvida de que, sob o ponto de vista científico, não há línguas mais adiantadas ou menos adiantadas, mais funcionais ou menos funcionais, mais elaboradas ou menos elaboradas do que outras. A Lingüística contemporânea dedicou inúmeras páginas a esse assunto e demonstrou ad nauseam a veracidade dessa afirmativa. A questão não se refere apenas à comparação entre as línguas. No interior das próprias línguas o axioma se repete: não existem modalidades, variações, falares ou dialetos melhores ou piores do que outros, sob o ponto de vista exclusivamente lingüístico.

Se a questão assim se coloca sob o ponto de vista científico o que é feito, evidentemente, pelos lingüistas -, tal não se dá quando nos referimos a uma avaliação social ou cultural da língua, que é feita por seus próprios usuários. Mesmo no Brasil, em que se constata um deficit histórico crônico no que diz respeito à educação, parece que há uma grande tendência em se valorizar a escolaridade, o estudo, o saber. Essa valorização está relacionada não só com os conteúdos apreendidos, mas também com o manejo adequado do instrumento que conduz ao domínio desses conteúdos. Em outras palavras, o cidadão comum valoriza o tipo de língua que é usado pelas camadas mais escolarizadas de uma sociedade. Esse tipo de língua tem mais prestígio entre as pessoas. Tanto é verdade que constitui um ideal lingüístico constantemente perseguido, que se nota facilmente nas escolas, em cursos especiais, em seções de jornais, em consultórios 
gramaticais veiculados pela televisão, na publicação de livros, etc. Por outro lado, o linguajar de pessoas menos escolarizadas não é um ideal lingüístico almejado pelo cidadão comum; de fato, esse linguajar não é ensinado nas escolas, não se tem notícia de cursos especiais com esse objetivo e a mídia impressa e falada não se preocupa com esse problema. É interessante observar que esse ideal lingüístico coletivo, tão antigo quanto a própria língua e tão insistentemente presente na sociedade letrada contemporânea, é ignorado por algumas faculdades de Letras e por alguns professores dessas escolas, que se negam a discutir ou a reconhecer esse problema. Uma conseqüência nefasta dessa atitude é o surgimento dos "comandos paragramaticais", para usarmos uma expressão de BAGNO (2000, p. 61), muitas vezes capitaneados por professores mal informados e mal formados, que se servem da mídia falada e impressa para prescrever normas lingüísticas, muitas vezes esdrúxulas e caducas. Não somos contra a existência dos comandos paragramaticais, desde que sejam conduzidos por profissionais esclarecidos, competentes e, principalmente, despreconceituosos. Dizemos isso porque a medicina, a economia e a psicologia, por exemplo, mantêm esses consultórios alternativos, que podem prestar serviços à comunidade, desde que sejam oferecidos, como dizíamos, por profissionais competentes.

Estreitamente ligado à questão do prestígio social e cultural da língua padrão, não devemos nos esquecer de que, na sociedade contemporânea, que é essencialmente letrada, o domínio dessa língua padrão adquire contornos especiais, pelo fato de se constituir uma espécie de conditio sine qua non para a ascensão social do indivíduo (SOARES, 1993; TRAVAGLIA, 1996; ROCHA, 1999). De fato, o que se observa é que o ingresso na sociedade escolarizada e letrada em que vivemos, quer sob o ponto de vista profissional, quer sob o ponto de vista sócio-cultural, se dá concomitantemente com a aquisição da modalidade lingüística culta de uma sociedade, presente no falar ou na escrita dos indivíduos mais escolarizadas. A língua padrão torna-se uma espécie de passaporte para o ingresso do 
cidadão na classe social imediatamente mais elevada. Uma prova disso é que a aceitação dos indivíduos nas universidades, no serviço público e nas empresas particulares se faz, via de regra, mediante uma prova escrita em que se testa a capacidade do candidato em usar o português culto e, muitas vezes, mediante uma prova oral - a célebre entrevista - em que os examinadores também testam a capacidade do indivíduo em se expressar em língua padrão falada.

Defendemos, portanto, o ponto de vista de que, sob o ponto de vista sócio-cultural, do mesmo modo como há modelos de vestimenta, de gestos, de postura e de comportamento, também há modelos de linguagem, uma vez que língua e sociedade, língua e cultura, língua e indivíduo estão intrinsecamente ligados. Por outro lado, repelimos a idéia de que há uma única língua padrão, válida urbe et orbe, bic et nunc. Na verdade, pode-se falar em algumas modalidades de língua padrão, como veremos neste trabalho.

Consideramos como língua padrão aquela modalidade de linguagem que é empregada pelas camadas mais escolarizadas de uma sociedade. Essa idéia não é nova. ALONSO \& UREÑA (1964, p. 16) já afirmavam em sua Gramática: "São formas corretas de dizer aquelas aceitas e usadas pelos grupos mais cultos da sociedade. Correção quer dizer aqui prestígio social de cultura" (grifos do autor). Vê-se, portanto, que o conceito de correção de ALONSO \& UREÑA não se apóia em posturas antiquadas, falsas e preconceituosas, que se baseiam em riqueza, poder político, linhagem, supremacia regional ou mesmo, pura e simplesmente, tradição ("formas aceitas e usadas" - grifo nosso).

Mesmo que o espectro das variedades lingüísticas seja muito variado e rico, é possível separar a língua em dois grandes blocos: a língua formal e a língua informal. Cremos, no entanto, que essas duas modalidades de língua podem ser mais bem caracterizadas se a divisão for feita em termos de língua escrita e de língua falada. De fato, é na escrita que a língua formal melhor se consubstancia, da mesma maneira que é na fala que a língua informal está mais presente. 
Para simplificar a questão, sem o intuito de mutilá-la, podemos dizer que o estatuto da linguagem escrita é diferente do estatuto da linguagem falada. Embora se trate da mesma língua, ninguém pode negar que as duas modalidades apresentam características diferentes. Com isso estamos querendo dizer que o português padrão empregado na língua escrita não pode servir de modelo para a língua falada e vice-versa. Esse truísmo, que nos parece tão simples e óbvio, não é levado em consideração por diversas pessoas, que não fazem a devida distinção entre língua falada e língua escrita. É como se devêssemos falar como se escreve, ou seja, como prescrevem as gramáticas tradicionais. Tomemos o exemplo que se segue.

Consideremos a crônica abaixo, transcrita do jornal Correio Braziliense (infelizmente não temos os dados bibliográficos relativos à crônica, pois ela nos foi passada por um aluno):

\section{"A BELA E A FERA}

Vera Fischer reaparece na telinha global. Os telespectadores vibram com os olhos azuis no rosto perfeito. A musa responde às perguntas do Faustão.

'Como está seu relacionamento com a imprensa?', pergunta a Fera. 'Há repórteres bons e maus', diz a Bela. 'Eu prefiro muito mais me lembrar das pessoas sérias do que das outras.'

'Ela deve ter ouvido o galante Pedro Malan', desculpam-na os fãs. O ministro tropeça no verbo preferir a torto e a direito.

Outro dia, despejando charme, disse displicente: 'Prefiro juros altos do que inflação alta'.

Preferir exige tratamento especial. Preferência é distinção. Destaque. O top dos tops. Por isso não se diz 'prefiro mais'. O mais está incluído nele.

Dica: Quem prefere prefere alguma coisa a outra.

Prefiro cinema a teatro. A lourona teria sido perfeita se tivesse dito. Eu prefiro me lembrar das pessoas sérias a me lembrar das outras. E o todo poderoso senhor das finanças teria abafado com a regência certa: Prefiro juros altos a inflação alta."

Observe-se que o cronista censura a atriz e o ministro pelo fato de não usarem o modelo da língua padrão escrita. Na verdade a 
estrutura usada por eles é a do padrão culto da língua falada, já que a grande maioria das pessoas com curso superior emprega essa construção quando está conversando.

Do exposto, conclui-se que há pelo menos duas modalidades de língua padrão: a da língua escrita e a da língua falada. A escrita é mais ou menos a mesma em todo o País, embora se possa apontar distinções entre a língua formal e a jornalística, como veremos a seguir. Já a língua padrão falada não é tão coesa como a escrita. O que se observa é que, mesmo considerando-se apenas as camadas mais escolarizadas das diversas regiões do país, haverá variações entre elas, como, por exemplo, na execução de certos fonemas $(/ s /$ chiado e sibilado, $/ r$ / velar ou retroflexo), na pronúncia de certas formas verbais (/pêgo/ ou /pégo/), na prosódia de alguns substantivos (/xérox/ e /xerox) e no emprego dos pronomes e das formas verbais (tu vai) tu vais).

Apesar dessas diferenças, há certas estruturas sintáticas que podem ser consideradas como padrão de língua falada em todo o País, embora sejam distintas do padrão da língua escrita. Estamos nos referindo, por exemplo, ao emprego do verbo ter com o sentido de existir e à colocação do pronome oblíquo no início da frase. Pelo fato de serem essas estruturas normais na fala das pessoas mais escolarizadas, devemos considerar, por uma questão de lógica, que essas estruturas caracterizam o português falado culto de diversas regiões do Brasil. Como afirma SENA (1986, p. 75), "a norma lingüística é uma realidade que se constata através de pesquisas, e estas hoje se baseiam, como já vimos, no critério da freqüência. O que é freqüente no uso de uma variedade da língua é que constitui a norma”.

É preciso deixar claro - em resumo - que tanto a frase da atriz Vera Fischer - "Eu prefiro muito mais me lembrar das pessoas sérias do que das outras", quanto a frase do ministro Pedro Malan - "Prefiro juros altos do que inflação alta"- são construções da linguagem culta falada, porque são "aceitas e usadas pelos grupos mais cultos da sociedade", como afirmam Alonso e Ureña. Quanto às correções efetuadas pelo cronista ("Eu prefiro me lembrar das pessoas sérias 
$a$ me lembrar das outras" e "Prefiro juros altos $a$ inflação alta"), cumpre dizer que se trata de construções empregadas na língua culta escrita. Vale uma última observação a respeito do texto em análise, confirmando o que dissemos linhas acima a respeito dos comandos paragramaticais, que muitas vezes são elaborados por pessoas mal preparadas para a tarefa. No texto em questão, o autor condena a regência usada pela língua falada padrão, mas faz uso de palavras e expressões coloquiais/emotivas/enfáticas, características da linguagem descontraída e/ou poética, como: telinha global, olhos azuis no rosto perfeito, o ministro tropeça no verbo, despejando charme, o top dos tops, a lourona, o todo poderoso, teria abafado... Trata-se de dois pesos e duas medidas. Qual é o critério adotado pelo autor ao condenar a regência popular do verbo assistire ao aceitar as palavras e construções assinaladas?

\section{3. $O$ aspecto lingüístico}

Parece não haver dúvida de que a chamada língua padrão existe. Este trabalho, por exemplo, bem como as leis, os livros técnicos e científicos (incluindo os didáticos), os contratos, a correspondência oficial, os manuais de instrução, as receitas e os avisos públicos estão redigidos nessa modalidade de língua. Pretendemos ainda, nas páginas que se seguem, delimitar com mais rigor a abrangência dessa língua padrão. Por ora, gostaríamos de fazer uma pergunta anterior ao que estamos discutindo: o que é a língua padrão? Em outras palavras: se uma pessoa quer escrever na chamada língua padrão, em que essa pessoa deve se basear? É provável que a resposta mais comum seja que ela deve ter como base as regras da gramática. Gostaríamos de ir mais a fundo na questão e perguntar: e as regras da gramática são baseadas em quê? Aqui é que se situa um dos grandes problemas da gramaticologia brasileira.

Há uma tradição dos gramáticos brasileiros em se considerar como base para a fixação das regras gramaticais as obras literárias dos escritores brasileiros e portugueses. 
No prefácio da Nova gramática do português contemporâneo, CUNHA \& CINTRA (1985) afirmam a respeito de sua obra:

"Trata-se de uma tentativa de descrição do português atual na sua forma culta, isto é, da língua como a têm utilizado os escritores portugueses, brasileiros e africanos do Romantismo para cá, dando naturalmente uma situação privilegiada aos autores dos nossos dias."

Observe-se que na Gramática de CUNHA \& CINTRA, os escritores portugueses, brasileiros e africanos - com todos os seus regionalismos, idiomatismos e coloquialismos - são citados como modelos de linguagem padrão.

CEGALLA (1979), no prefácio de sua Gramática, é também muito claro com relação ao assunto:

"Na bibliografia que figura no fim do livro encontrará o estudante minuciosa referência às fontes consultadas bem como a relação das principais obras literárias de onde extraímos as abonações e os exemplos que servem de apoio à teoria gramatical."

LIMA (1972, p. 6), por sua vez, afirma em sua Gramática normativa da lingua portuguesa:

"Fundamentam-se as regras da Gramática Normativa nas obras dos grandes escritores, em cuja linguagem as classes ilustradas põem o seu ideal de perfeição, porque nela é que se espelha o que o uso idiomático estabilizou e consagrou."

É interessante observar que essa aura de sacralidade de que se reveste a língua dos escritores pode ser constatada também entre os lexicógrafos. Basta conferir na bibliografia do conhecido AURÉLIO (FERREIRA, 1975) o número elevado de escritores citados, de cujas obras são extraídas as abonações do Dicionário.

Parece não haver dúvida, portanto, de que as gramáticas tradicionais estabelecem como córpus de onde são extraídas as abonações para a fixação das regras gramaticais os textos de autores de literatura. Essa é uma posição com a qual não concordamos e que tem que ser revista com urgência. Analisemos primeiramente a questão da língua literária contemporânea. Repetimos aqui a 
pergunta feita no início deste item: devem as leis, os livros técnicos e científicos, os contratos, a correspondência oficial, os manuais de instrução, as receitas e os avisos públicos ser redigidos na mesma modalidade de língua em que se expressam os autores contemporâneos? É evidente que não. Vejamos o porquê do problema.

Ortega y Gasset já dizia: "Que não se atreva a escrever aquele que não se atreva a inovar" (apud CUNHA, 1977, p. 31). Estamos entendendo escrever, é claro, no sentido de escrever com finalidades estéticas. De fato, ninguém pretende inovar, sob o ponto de vista lingüístico, ao escrever um regulamento, ao redigir uma petição ou ao fazer um relatório técnico. Tal não se dá quando a pessoa escreve com finalidades artísticas, como afirma Ortega y Gasset. Tomemos como exemplo a língua literária do Modernismo, ou seja, a língua literária contemporânea. Ela se caracteriza pela ruptura com relação aos cânones da gramática tradicional. Sabemos que essa é uma atitude programática de certos escritores, que se observa não só na teoria como também na prática.

Se a língua literária contemporânea se caracteriza pela ruptura, pela inovação e pela rebeldia, conclui-se que ela não pode servir de modelo para a chamada língua padrão, que é essencialmente conservadora. Pode-se mesmo supor que inúmeros autores contemporâneos sentir-se-iam ofendidos se o tipo de linguagem usado por eles fosse guindado à categoria de linguagem oficial, burocrática e conservadora das escrituras, dos acórdãos, dos regulamentos e dos laudos técnicos. É claro que há autores contemporâneos que não rompem com a tradição idiomática. Mas é aconselhável tomar a língua literária - in totum - como padrão, mesmo sabendo-se que há autores que rompem com essa tradição e os que não rompem? De onde devem ser extraídas as abonações? Dos autores revolucionários ou dos conservadores? Lembremo-nos, antes de tudo, que estamos tentando fixar os córpus de onde devem ser extraídas as abonações que servirão de modelo para a fixação das regras gramaticais. É uma questão de petição de princípio. Não faz sentido dizer que tal escritor pode servir de modelo, porque segue as regras gramaticais. Para 
efeito de raciocínio, as regras gramaticais não existem. Estamos querendo, justamente, fixar o córpus de onde serão extraídas as regras gramaticais, do mesmo modo como quando queremos descrever a linguagem dos "trombadinhas" de Belo Horizonte: é dos textos, ou seja, das falas - in totum - que devemos partir para fazer a descrição.

A língua literária contemporânea caracteriza-se, portanto, pela possibilidade de rebeldia com relação à tradição gramatical, não podendo, portanto, ser considerada como modelo para a língua padrão.

Se a língua literária contemporânea não deve servir de modelo para a língua padrão, como tentamos demonstrar, por outro lado, também não faz sentido eleger a língua literária dos séculos anteriores como modelo da língua padrão atual, como fazem as gramáticas tradicionais. Será que os jornalistas, os advogados, os cientistas sociais e os lingüistas devem usar a língua como o fizeram os escritores dos séculos 16, 17, 18 e 19? Com todo respeito a Luís de Camões e a Antônio Vieira, dois dos maiores portentos da literatura de língua portuguesa, cremos que nenhum jornalista, advogado ou sociólogo gostaria de escrever seus trabalhos com o mesmo tipo de linguagem utilizado pelos escritores citados. Na realidade, não é isso o que acontece. Uma coisa é admirar a obra inigualável de Camões, as composições divinas de Mozart ou a decoração refinada do Palácio de Versailles. Mas, verdade seja dita, ninguém hoje escreve como Camões, compõe como Mozart ou levanta edificações como o palácio de Versailles. Ora, se tudo evolui, por que a língua não pode também evoluir?

Em síntese, podemos afirmar com SENA (1986, p. 96-97), a respeito da distinção entre língua padrão e língua literária: "É certo que as duas modalidades de língua estão unidas por um núcleo comum, mas não têm necessariamente de servir de modelo uma para a outra." Mais adiante o autor conclui: 
"[a língua padrão] existe, porque os países civilizados necessitam de um padrão lingüístico, mais ou menos uniforme, com função referencial, que possa servir de instrumento de comunicação às diversas ciências e aos documentos oficiais. A da literatura existe, porque, conforme Vendryes (op. cit., 301), "l'homme de lettres a besoin d'un instrument personnel, qui exprime ce qu'il y a de particulier dans son intelligence et sa sensibilité”.

Resumindo, podemos dizer que o importante a se considerar neste trabalho é que os textos literários não podem servir de modelo para a fixação da norma culta do português do Brasil. É necessário que os professores de Português se conscientizem disso e mostrem claramente esse ponto de vista aos alunos, por meio do estudo de textos técnicos e jornalísticos. Tanto os textos em língua formal (presentes em livros técnicos e científicos, artigos, correspondência oficial, relatórios, regulamentos, etc.) quanto os textos em língua jornalística, apesar da diferença de estilo que os separa, caracterizam o que se pode chamar de língua padrão escrita do português contemporâneo e é desses tipos de produção lingüística que devem ser extraídos os textos dos livros didáticos de Português e as abonações que servirão de base para fixação das regras gramaticais que descreverão a língua culta escrita do português do Brasil. Essa postura não é novidade entre os que se preocupam com o ensino de Português. PERINI (1985, p. 88) já afirmava há mais tempo: "É por razões como essas que gostaria de sugerir que a gramática seja (pelo menos em um primeiro momento) uma descrição do português padrão tal como se manifesta na literatura técnica e jornalística”. POSSENTI (1997, p. 41) defende o mesmo ponto de vista: "Haveria certamente muitas vantagens no ensino de português se a escola propusesse como padrão ideal de língua a ser atingido pelos alunos a escrita dos jornais ou dos textos científicos, ao invés de ter como modelo a literatura antiga". É evidente que o professor de Português deverá também se preocupar com a apreciação de textos literários e de outros tipos de texto em sala de aula, mas esse é um assunto que escapa aos objetivos deste artigo. Sugerimos ao leitor que consulte a obra Gramática: nunca mais (ROCHA, 2002) em que essas questões são 
discutidas. De qualquer forma, essa confusão de objetivos - ensinar a língua padrão com base na língua literária ou deixar de ensinar a língua padrão - tem sido um dos grandes equívocos no ensino de Português e tem contribuído para a sua deterioração.

\section{O ENSINO DA LÍNGUA PADRÃO SEM O ESTUDO DA GRAMÁTICA}

Voltemos agora a nossa atenção para o problema do ensino da língua padrão. O Projeto GNM prevê que o aluno, ao final da $8^{a}$ série, domine razoavelmente a "língua padrão do português do Brasil", ou seja, que ele tenha a capacidade de usar essa modalidade de língua.

Como deve ser o ensino do português padrão? Para responder a essa questão, vamos dividir a resposta em três partes, que serão desenvolvidas nos subitens que se seguem:

2.1 O ensino da língua padrão deve ser feito de maneira eficiente, organizada e sistemática;

2.2 O estudo da gramática é prejudicial aos alunos;

2.3 É possível ensinar português padrão com eficiência e organicidade sem o auxílio da gramática.

\subsection{O ensino da língua padrão deve ser feito de maneira eficiente, organizada e sistemática}

Como dissemos anteriormente, há algo no ensino de português que não está funcionando adequadamente. Um adolescente de 13/ 14 anos encontra-se numa fase especial da vida, em que tem a capacidade de assimilar os mais diversos conhecimentos, de raciocinar da maneira mais fecunda, de decifrar as mais complicadas fórmulas e de analisar/interpretar/estabelecer relações/deduzir/ concluir a respeito dos mais variados assuntos. Apesar de conviver cotidianamente com a língua padrão na escola durante oito anos no mínimo -, há aluno que conclui a oitava série sem ser capaz de escrever um texto razoável, de acordo com as normas do dialeto 
padrão (como lhe será exigido pela sociedade letrada em que vive). Evidentemente que a culpa não é do aluno, como dissemos anteriormente, mas do ensino equivocado do Português, da maneira como tem sido feito em nossas escolas. Parece que boa parte dos professores dessa disciplina está perdida, sem saber exatamente o que ensinar aos alunos. Isso se deve, em parte, ao grande número de teorias, escolas e modismos que assolaram o ensino da língua materna nos últimos vinte ou trinta anos. Saímos de um gramaticismo extremo e passamos por várias fases ou correntes, como: o estruturalismo exageradamente descritivista, a linha francesa da interpretação de textos, o gerativismo, a teoria da comunicação com o laissez-faire chacriniano, a escola funcional, a teoria construtivista, etc.

O que está acontecendo com o ensino de Português parece estar relacionado com a questão levantada por ZAGURY (1994) em Sem padecer no paraíso: em defesa dos pais ou sobre a tirania dos filhos. Nessa obra, que trata do relacionamento entre pais e filhos, a autora faz uma análise da passagem do rigorismo da educação tradicional para a educação liberal contemporânea. O problema é que, com relação à educação liberal contemporânea, muitos pais estão perdidos, não sabem agir com relação aos filhos. Mutatis mutandis é o que está acontecendo com o ensino de Português. A impressão que se tem é a de que há muitos professores perdidos e de que cada professor conduz o barco à sua maneira. Não se propõe aqui um monitoramento robotizado do docente, mas que sejam traçados, com muita clareza, os objetivos básicos do ensino do Português. É isso o que pretendemos fazer neste trabalho. O texto que se segue (VIEIRA, 1998, p. 94) resume bem o que estamos querendo dizer:

"Embora as exceções sejam numerosas, encontram-se ainda, entre os professores de português, dois tipos extremos. De um lado, aqueles mais tradicionais que organizam seus cursos, segundo modelos antigos, nos quais privilegia-se a transmissão de 'pontos' da gramática normativa, acompanhada de exercícios de avaliação. Para eles, o conhecimento das regras e exceções da gramática normativa permite que os alunos escrevam, leiam e falem da melhor maneira possível. De outro, aqueles que acreditam na criatividade 
do aluno e na espontaneidade do ensino. Cada aula é uma aventura, onde cada um toma o seu barco e segue o seu rumo. Não há conteúdos, não há objetivos, não há direção. As conseqüências das duas atitudes são bem conhecidas, e dispensam comentários."

Na verdade, não se sabe o que é pior para o ensino de Português: o professor "antiquado", que só se preocupa com a correção da linguagem em todas as circunstâncias e com o ensino da gramática tradicional, ou o professor "moderninho", adepto do laissez-faire, que acha que tudo é válido em linguagem desde que se logre comunicar e que, em conseqüência disso, passa todo o ano apenas "admirando" as letras de música e os textos de publicidade, esperando que, com isso, o aluno seja capaz de construir textos eficientes para, por exemplo, estudar outras disciplinas ou se expressar em português padrão.

O que falta ao ensino de Português é uma maior eficiência, no sentido de que ele deve ser organizado e sistemático, como é o ensino de qualquer disciplina ou de qualquer ramo do conhecimento humano.

Não há dúvida de que o estudo de texto e a redação são elementos importantíssimos para a aquisição da modalidade culta da língua materna. Mas o aluno não pode passar oito anos do curso fundamental apenas lendo e produzindo textos. Embora haja alunos que cheguem à oitava série dominando esse tipo de língua, apenas com essa prática, é preciso garantir efetivamente a todos os alunos o domínio da língua padrão ao final da oitava série. É preciso lembrar que a prática da leitura e produção de texto tem sido feita de maneira desorganizada, assistemática. Falta ao ensino da língua padrão uma organicidade e uma sistematização. Não podemos nos esquecer de que a inteligência humana - no caso, a dos adolescentes - clama por raciocínios lógicos e coerentes. Embora a língua padrão em si seja em muitos casos convencional, a aquisição dessa língua deve ser feita de maneira lógica e coerente. 


\subsection{O estudo da gramática é prejudicial aos alunos}

Neste trabalho estamos defendendo a idéia de que o estudo da gramática, seja ela qual for - normativa, descritiva, de uso, instrumental, funcional, teórica, reflexiva, estrutural, gerativa, tradicional, histórica, etc. -, é não só dispensável, como também prejudicial ao aluno. Estamos entendendo gramática como sendo uma disciplina, um tratado, uma técnica ou uma ciência que se preocupa com a descrição e/ou interpretação dos fenômenos lingüísticos. Cumpre dizer que essa é a definição mais usual do termo (cf. o dicionário conhecido como Aurélio). Essa descrição e/ou interpretação - que, por natureza, é explícita e envolve uma terminologia própria - é feita, via de regra, através de estudos específicos, como artigos, teses, livros, comunicações, etc., ou através dos chamados compêndios gramaticais. Tal delimitação torna-se necessária, porque há autores que afirmam, como TRAVAGLIA (1997, p. 178), que "texto é a gramática da língua em funcionamento". Embora concordemos com essa afirmativa, acrescentamos, porém, que ela só faz sentido para os lingüistas e gramáticos, que conseguem "enxergar" no texto elementos da gramática de uma língua. O falante comum usa a língua, via de regra, como um meio de comunicação ou de informação, ou com a finalidade de expressar seus sentimentos, sendo raras as vezes em que se volta para as questões metalingüísticas. Entendemos que "saber usar uma língua" não é conhecer a estrutura, o funcionamento, a gramática dessa língua, do mesmo modo como "saber usar um automóvel”, isto é, saber dirigir um automóvel não é conhecer a sua estrutura, o seu funcionamento, a sua "gramática". De acordo com a teoria chomskyana, podemos considerar que pensar, andar, respirar e falar são fenômenos similares e fazer uso deles não implica ter conhecimento consciente de seu funcionamento. Não estamos nos referindo, portanto, neste trabalho, à gramática subjacente, que é inerente a todo falante nativo, mas de acesso, percepção e descrição extremamente difíceis. Que o digam os gramáticos gerativistas!

Para defender o ponto de vista aqui adotado, de que o estudo da gramática é prejudicial ao aluno, vamos tentar, nos itens que se 
seguem (2.2.1 a 2.2.8), destruir alguns mitos relacionados com o ensino da gramática.

\subsubsection{Saber português e saber gramática}

Antes de mais nada, gostaríamos de deixar bem claro que existe uma diferença fundamental entre saber Português - aqui entendido como saber usar a língua - e saber gramática. Também com relação ao domínio da norma culta, pode-se afirmar que uma coisa é saber redigir um texto em língua padrão e outra é saber classificar as orações, distinguir as classes de palavras, estabelecer diferenças entre raiz e radical, etc. É evidente que, para se fazer uso da língua literária e da língua falada, também não é necessário saber gramática.

Neste trabalho estamos preocupados basicamente com a língua padrão. É possível encontrar alunos do curso fundamental principalmente nas séries finais - que escrevam satisfatoriamente, sem saber gramática. Essa parece ser uma constatação óbvia. Na verdade, são raros os alunos que sabem gramática, mesmo que escrevam bem. Por outro lado, tudo indica, com relação aos alunos que não escrevem satisfatoriamente, que a sua deficiência não está relacionada com o fato de não saberem gramática. $\mathrm{O}$ aluno escreve mal, não é porque não saiba gramática, mas porque apresenta um outro tipo de deficiência, como, por exemplo, o fato de não ter uma orientação adequada com relação à prática da escrita. Podemos resumir a questão do seguinte modo: se o aluno escreve mal, ou não sabe usar o português adequadamente, não serão as aulas de gramática que melhorarão seu desempenho. Se ele escreve bem, se ele sabe adequar a sua língua às diversas circunstâncias de uso, qual seria a utilidade dessas aulas? Não faz sentido, portanto, a afirmativa de que para aprender português é necessário saber gramática. Vale a pena registrar estas palavras de LUFT (1993, p. 24): "minha experiência de professor me ensinou que os alunos mais talentosos em linguagem, futuros escritores, são os mais avessos a aulas de Gramática" (grifo do autor). Repetimos, portanto, que saber Português e saber 
gramática são duas atividades distintas. Essa distinção se faz necessária, porque há um grande número de pessoas que pensa que saber Português é saber gramática. Mesmo entre os teóricos do assunto, notase às vezes uma certa confusão, como nesta passagem de BECHARA (1985, p. 16-17): "o ensino dessa gramática escolar, normativa, é válido, como o ensino de uma modalidade 'adquirida', que vem juntar-se (não contrapor-se imperativamente!) a outra, 'transmitida', a modalidade coloquial ou familiar." Com todo respeito à posição do autor, a nosso ver, a questão deve ser apresentada da seguinte maneira: o ensino da língua padrão é válido, como o ensino de uma modalidade "adquirida", que vem juntar-se (não contrapor-se imperativamente!.) a outra, "transmitida", a modalidade coloquial ou familiar.

São por demais citados os exemplos de escritores consagrados que dizem não conhecer gramática. Um dos casos mais conhecidos é o de Luís Fernando Veríssimo (apud LUFT, 1993, p. 15): “... a intimidade com a Gramática é tão dispensável que eu ganho a vida escrevendo, apesar da minha total inocência na matéria”. Até mesmo Machado de Assis, em depoimento a Medeiros de Albuquerque (apud LUFT, 1993: 24), chegou a afirmar que tinha aberto uma gramática de um sobrinho, "e ficara assombrado da própria ignorância: não entendera nada!".

Alguns defensores do ensino gramatical na Escola poderão concordar que escritores, professores de outras disciplinas, jornalistas e advogados, dentre outros, não sabem gramática, mas, para chegarem ao estágio em que se encontram - em que são obrigados a usar a língua constantemente - foram obrigados a aprender gramática na Escola. Essa afirmativa parece-nos gratuita. Primeiramente, porque há inúmeros "profissionais do idioma" que confessam nunca ter aprendido gramática nos bancos escolares. Em segundo lugar - e este é o argumento que nos parece mais importante - é possível encontrar em nossas escolas de nível secundário inúmeros alunos que escrevem bem e corretamente, sem saber gramática. Se é possível escrever bem e corretamente sem o aprendizado da gramática, conclui-se que ela é dispensável.

Ora, se para aprender a língua padrão não é necessário estudar gramática, qual seria a real utilidade de se aprender gramática no 
curso fundamental? Cremos que nenhuma. O tempo precioso que se gasta nas aulas de Português para se estudar teoria gramatical deveria ser aplicado em atividades muito mais práticas, úteis e compensadoras para os alunos, como veremos neste trabalho. É por isso que consideramos que o ensino da gramática na Escola é prejudicial ao aluno.

\subsubsection{Gramática e raciocínio lógico}

Alguns professores afirmam que a gramática é útil no curso secundário, porque leva o aluno a desenvolver o raciocínio, o pensamento lógico, a capacidade de induzir, deduzir, comparar, concluir, abstrair, estabelecer causas e conseqüências, etc. Consideramos essa posição equivocada, por vários motivos. Vamos, porém, aternos ao essencial: a língua deve ser considerada como um meio e não, como um fim. No nível secundário o importante é levar o aluno a ler e a escrever adequadamente. A atividade de comparar, deduzir, concluir, etc., deve ser feita - e efetivamente tem sido feita - com os conteúdos de outras disciplinas, como as Ciências Naturais, a Matemática, a Geografia, a História, além, é evidente, do estudo e interpretação de textos da nossa disciplina. Mas é preciso considerar, por exemplo, que, para o desenvolvimento do pensamento lógico, o estudo da Matemática é inegavelmente melhor do que o estudo da gramática. Portanto, como afirma VILELA (1995, p. 37), “... estabelecerse um conteúdo como objeto de estudos unicamente como pretexto para se fazer um exercício de inteligência, não chega a ser a melhor alternativa, uma vez que tantos outros conteúdos poderiam representar, para o aluno, mais vantagens e mais prazer." É claro que a interpretação de textos literários, quer se trate de excertos, quer se trate de obras inteiras (como na leitura extraclasse), é de fundamental importância para a visão do mundo, o que vale dizer, para o desenvolvimento do raciocínio lógico. Mas, repetindo, o domínio da língua padrão deve ser encarado como um meio e não, como um fim. 
Suponhamos que seja possível concordar com essa posição: de que o estudo da gramática contribui para o desenvolvimento do raciocínio lógico do aluno. É preciso considerar, no entanto, que a própria descrição gramatical, da maneira como tem sido feita pela gramática tradicional, é, em linhas gerais, incoerente, ilógica, irracional, apresentando, portanto, uma série de problemas e contradições. Como afirma DILLINGER (1995, p. 33):

“... as definições que essas gramáticas propõem são incoerentes, tanto dentro de uma gramática, quanto entre uma gramática e outra. Por exemplo, uma gramática conceitua 'sujeito' como o 'ser que pratica a ação do verbo' enquanto outra gramática o define como 'o elemento da frase com o qual o verbo concorda'. HAUY (1987) dedica um livro inteiro à identificação e exemplificação dessas incoerências nas gramáticas mais usadas do Brasil. PERINI (1986) também discute este mesmo problema."

A impressão que se tem é de que os professores de Português têm o costume de "empurrar" para os alunos os diversos conceitos gramaticais, pouco importando se esses conceitos são lógicos, compreensivos, coerentes, etc. Os alunos, pobres coitados, não têm argumentos para contestar a "sabedoria" do professor, mesmo porque lhes foi passado que o aprendizado da gramática é algo sagrado: equivale mais ou menos ao aprendizado da Bíblia. Discordar da gramática, assim como discordar da Bíblia, é um ato de heresia. Isso nos faz lembrar estas palavras do naturalista inglês, Charles Darwin (DARWIN, 2000, p. 49), a respeito de certos conteúdos que eram ensinados em sua escola: "nunca me ocorrera o quanto era ilógico eu dizer que acreditava no que não conseguia compreender e que, na verdade, era ininteligível".

\subsubsection{Necessidade de um estudo autêntico e coerente da gramática no ensino fundamental}

Algumas pessoas afirmam que o estudo do Português vai mal, porque não se faz nas escolas um estudo sério e aprofundado da gramática tradicional. 
É preciso considerar, no entanto, que há inúmeras questões apresentadas pela gramática tradicional que permanecem mal resolvidas pelos gramáticos há anos e anos. Dentre os problemas apontados por DILLINGER (1995) - como também por PERINI (1986), HAUY (1987), etc. - , convém lembrar questões aparentemente banais e que são ensinadas corriqueiramente pelos professores em sala de aula, mas que, se forem analisadas a fundo, apresentam dificuldades que só podem ser discutidas e analisadas nos cursos de graduação em Letras, ou mesmo de pós-graduação. São questões do tipo: classes de palavras, distinção entre adjetivo e advérbio ou entre preposição e conjunção, caracterização das flexões nominais, diferença entre substantivo concreto e abstrato, etc. Isso para ficarmos na "matéria" que é dada nas séries iniciais do curso fundamental. De duas, uma: ou o professor dá uma "tintura superficial" com relação aos problemas desse tipo (muitas vezes obrigando o aluno a decorar as questões gramaticais) - o que é deplorável, porque os alunos acabam percebendo, às vezes inconscientemente, a ilogicidade e a impraticabilidade dessa postura - ou o professor se cala definitivamente sobre esse assunto (o estudo da gramática explícita) e parte para soluções incertas, indecisas, inseguras, em que "cada aula constitui uma aventura, onde cada um toma o seu barco e segue o seu rumo", como vimos com VIEIRA (1992, p. 94).

É necessário deixar claro que é impossível fazer uma análise coerente, lógica e satisfatória das questões gramaticais em nível fundamental por diversos motivos: por haver pouco tempo, por se estar propondo ao aluno uma atividade inócua, que não leva a resultados imediatos e mediatos, por não haver motivação por parte do aluno e do professor, mas também por ser uma atividade imprópria para a faixa etária de 7 a 14 anos. De fato, a análise lingüística, se se deseja que seja feita de maneira científica, ou seja, racional e despreconceituosa, é algo extremamente abstrato, teórico e profundo, como, por exemplo, são os estudos psicanalíticos, a física quântica e o cálculo matemático. Que se consulte qualquer livro de análise lingüística para se comprovar o que estamos dizendo. Cremos mesmo que a 
grande maioria dos professores, uma vez formada, dificilmente abre um livro de análise lingüística, o que, em si, não é nenhum desdoiro para o professor de Português, mas vem confirmar o ponto de vista, segundo o qual o estudo da lingüística e o ensino de português são atividades relacionadas, mas independentes. Um reflexo do que acabamos de dizer pode ser confirmado na passagem transcrita abaixo (BAPTISTA, 1980, p. 50). Após constatar a complexidade do estudo das locuções verbais desenvolvido pela Prof. ${ }^{\text {a }}$ Eunice Pontes em Verbos auxiliares em português e depois de citar o Aspects of the theory of syntax, de Chomsky, em que é discutido o mesmo assunto, a autora afirma:

"Entretanto, só podemos tratar da locução verbal com crianças de 10 a 12 anos, com critério simples e claro, embora já se possa já ir conscientizando-as de que é assunto controvertido ainda para estudiosos da língua e que, portanto, não cabe ao professor adotar uma posição radical e dogmática, mas deixar que a intuição lingüística do aluno se manifeste e o oriente."

Uma posição parecida é a que tem AZEREDO (1998, p. 164) com relação ao mesmo assunto (locuções verbais):

"Ordinariamente, tenho feito como a média dos professores de português, que cientes das fragilidades da análise que lhes compete ensinar, fingem alguma tolerância com a hesitação dos estudantes, e aceitam, de cabeça fria, que uma construção como 'o ladrão tentou escapar' seja classificada quer como período simples, com o verbo 'tentar' no papel de auxiliar, quer como período composto, com um verbo transitivo complementado por um infinitivo. Nosso consolo é que esta dúvida não acomete apenas o pessoal da linha de frente da batalha pedagógica."

A pergunta que deixamos registrada aqui é: vale a pena discutir com os alunos da $1^{\text {a }}$ à $8^{\underline{a}}$ série "um assunto controvertido ainda para estudiosos da língua" e "para o pessoal da linha de frente da batalha pedagógica", ou é melhor passar "uma tintura de verniz" para "tapear" os alunos? Parece que nem uma nem outra é a solução adequada, porque ambas pressupõem o ensino de gramática nas aulas de português, o que é, a nosso ver, dispensável. 
Quando se afirma que "a análise gramatical coerente e racional do português é uma atividade inadequada para alunos de nível fundamental", uma pergunta pode surgir: quando um aluno tem uma determinada dúvida em português, geralmente ele não recorre à gramática para sanar essa dúvida? Em outras palavras: se o professor afirma para o aluno que o "certo" é para eu fazer e não, para mim fazer, o aluno não vai perguntar por que, ou seja, não vai se interessar pela explicação gramatical que justifique essa solução? Vamos apresentar três respostas a essa questão.

Em primeiro lugar, é preciso reconhecer que a dúvida das pessoas normalmente não se refere à questão gramatical, mas ao emprego efetivo na fala ou na escrita de tal ou qual palavra ou expressão. Em isto épara mim/eu fazer, as pessoas não perguntam se mim/eu é o sujeito da oração, mas, simplesmente, "qual é o certo em português"? Na verdade, o que ocorre constantemente é que, ao dar a resposta considerada correta, muitas vezes o professor pergunta: "Você quer saber o porquê dessa resposta, ou seja, você quer saber a explicação gramatical da resposta?" Normalmente, antes que o professor de Português comece a explicação gramatical, o aluno já está longe - física ou mentalmente - pois não lhe interessam as justificativas gramaticais para tal ou qual desempenho lingüístico.

Em segundo lugar, vamos considerar a verdade contida no ditado: "o uso do cachimbo deixa a boca torta". Em outras palavras, em uma casa em que só se fala em pecado e em que tudo é pecado, é provável que na primeira vez em que a moça "pegar na mão do rapaz", ela seja acometida da dúvida: "será que isso é pecado?". A mesma coisa se diga com relação à aula de Português. Se o professor só dá aula com base na gramática, é provável que os seus alunos sejam acometidos freqüentemente de dúvidas gramaticais. Mas se o professor adota outros métodos em que não seja necessário o ensino da gramática explícita, é evidente que o aluno não será "atormentado" por essas dúvidas gramaticais.

Em terceiro lugar, é indispensável lembrar que as gramáticas são livros de difícil consulta. Na verdade, para se consultar a 
gramática, é necessário saber gramática, do mesmo modo como, para se consultar o Código Civil, é preciso ter conhecimentos de Direito Civil. E como hoje em dia poucas pessoas sabem gramática, obviamente, a consulta a um compêndio gramatical se torna uma tarefa difícil, penosa e cansativa para os alunos e para as pessoas em geral. Observe-se a dificuldade que terá o leigo para localizar uma resposta para a pergunta do parágrafo anterior ("isto é para mim/eu fazer"). Experimente também o leitor-leigo - e mesmo o não-leigo - encontrar na Nova Gramática do Português Contemporâneo, de CUNHA \& CINTRA (1985), as páginas referentes do estudo da crase! O leitor verá como é difícil encontrar esse assunto! Além disso, as gramáticas apresentam inúmeras teorias que, para o leigo, não têm nada a ver com o efetivo desempenho lingüístico do indivíduo na fala e na escrita. De fato, que proveito podem ter para o cidadão comum a classificação dos pronomes, a distinção entre as orações subordinadas substantivas e as subordinadas adverbiais e o estudo da fonética articulatória?

A solução para o problema é, a nosso ver, simples e lógica: se alguém tem dúvida com relação ao emprego de determinada expressão, a resposta deve ser procurada em livros que tratem do emprego efetivo de palavras, expressões e frases do português. De fato, a bibliografia nacional dispõe de bons livros que tratam do assunto. Esses livros devem ser de fácil consulta e não precisam usar terminologia gramatical. No final deste trabalho (bibliografia), o leitor encontrará indicações de alguns livros desse tipo.

\subsubsection{A incorporação dos termos gramaticais à fala comum do indivíduo}

Certas pessoas afirmam que o estudo da gramática é necessário, porque há alguns termos gramaticais que se aprendem na Escola e que são usados na linguagem cotidiana, sendo, portanto, úteis para toda a vida. São palavras como: sentença, frase, oração, palavra, singular, plural, masculino, feminino, verbo, adjetivo, sinônimo, antônimo, coletivo, etc. 
Em primeiro lugar, é preciso considerar que essas palavras não são em tão grande número, como se poderia pensar. Em decorrência disso, pode-se perguntar: justifica-se estudar anos e anos de gramática na Escola - roubando o tempo de outras atividades mais importantes - com o intuito de se aprenderem algumas poucas palavras relacionadas com o ensino da gramática e que serão usadas no dia-a-dia? Tudo indica que a resposta é negativa.

Em segundo lugar, há certas palavras, ou noções, que pertencem ao domínio comum, ou seja, não há a necessidade de que a criança passe pelos bancos escolares para incorporá-las ao seu léxico. A mãe não precisa esperar que o filho entre para a escola para lhe dizer: "- Meu filho, não diga mais essa palavra!" ou "- Que frase mais linda é essa!" O mesmo raciocínio se aplica ao fato de que o cidadão comum emprega vários termos e expressões da Psicologia em sua fala cotidiana, como transferência, projeção, ego-auxiliar, super-ego, stress, feed-back, libido, etc. Para conhecer esses termos, não há necessidade de se estudar Psicologia em curso superior.

Por fim, é preciso lembrar que, ao usarmos em nossos trabalhos e em nossos exercícios (como faremos no item 3 deste trabalho) vocábulos como, frase, palavra, coletivo, singular, plural, masculino, feminino, etc., temos consciência de que o faremos: $1^{\circ}$ ) de maneira muito parcimoniosa; $2^{\circ}$ ) com a certeza de que não estamos empregando esses termos no sentido técnico, mas no sentido geral que essas palavras possuem; $3^{\circ}$ ) certos de que jamais exigiremos de nossos alunos a definição e a classificação desses conceitos, como se faz na gramática tradicional.

\subsubsection{O estudo da "gramática essencial"}

Há uma boa parte dos professores de português que é partidária da seguinte posição: o ensino da gramática deve se limitar a certas noções básicas, essenciais, para que o aluno saiba um mínimo de gramática. Já consideramos anteriormente essa posição equivocada, porque não vemos utilidade em se aprender gramática, mesmo que 
seja "só o essencial". Além disso é difícil definir o que vem a ser esse "essencial". Há, porém, uma conseqüência mais grave nessa posição. Dá-se o que temos chamado em nossas aulas de "efeito arrastão", e que pode ser caracterizado da maneira que se segue.

Suponhamos que um professor considere que a noção de sujeito seja essencial para o estudo de português. Ao ensinar o que é sujeito, o professor precisará ensinar também o que é predicado. Acontece que algum aluno poderá perguntar se toda oração tem sujeito. Em vista disso, o professor dirá que não, que há orações sem sujeito. Como conseqüência, o professor se sentirá na obrigação de falar em sujeito indeterminado, sujeito oculto, sujeito posposto, e assim por diante. Aproveitando o "embalo", "para não perder a caminhada", o professor poderá falar em predicado nominal, verbal e verbonominal; em verbo intransitivo, transitivo direto, transitivo indireto, etc. Quando o professor der conta de si, já estará no fim do semestre, ou no fim do ano, e ele não terá ensinado "português" aos alunos, e sim, "gramática".

O mesmo se diga com relação a outras questões de português: como se poderá falar em substantivo, sem se falar em adjetivo, sem se falar em verbo, sem se falar em advérbio, etc.? O "efeito arrastão" é altamente pernicioso aos alunos, porque há certos professores de português que, quando começam a ensinar gramática a seus alunos, não param nunca mais. Como afirma FRANCHI (s/d), "e de 'assim por diante' em 'assim por diante' se vai empurrando para os alunos toda a gramática”. Como se vê, o PP não deve cair na tentação de ensinar "ao menos aquela teorização necessária para aperfeiçoar seus atos de comunicação", como sugere LUFT (1993, p.105):

“... mas ele [o aluno] ficará mais seguro, mais senhor de sua linguagem, se for levado a "saber" também conscientemente, explicitamente; depois da teorização implícita, intuitiva, construir alguma teorização explícita, discursiva, raciocinada, ao menos aquela teorização necessária para aperfeiçoar seus atos de comunicação". 


\subsubsection{A gramática e o conhecimento reflexivo da língua}

Há alguns autores que afirmam que o ensino gramatical é necessário ao aluno para que ele possa refletir a respeito de sua própria língua. A gramática reflexiva seria, portanto, um instrumental de que ele disporia para compreender melhor a estrutura, a essência do seu principal meio de comunicação. Ora, não existe uma maneira mais direta e efetiva para se conhecerem as entranhas de uma língua do que através do estudo de textos, quer se trate de textos informativos, como nas aulas de português, quer se trate de textos "libertários", como nas aulas de criação literária. Aliás é dessa maneira que entende o problema a publicação do MEC intitulada Parâmetros curriculares nacionais (MINISTÉRIO DA EDUCAÇÃO, 2000, p. 79), quando afirma: "no que se refere às atividades de leitura, o trabalho de reflexão sobre a língua é importante por possibilitar a discussão sobre diferentes sentidos atribuídos aos textos e sobre os elementos discursivos que validam ou não essas atribuições de sentido". Cumpre também lembrar que o estudo do vocabulário, que pode ser feito das maneiras mais variadas possíveis, constitui um ótimo meio para se refletir sobre a própria linguagem, como lembra BECHARA (1985, p. 28):

"Ainda sem sair do campo das ciências lingüísticas, pode o professor ampliar o conhecimento reflexivo do idioma nacional e do mundo objetivo que circunda o falante através do estudo e análise metódica do vocabulário, importante e extensa zona da língua que, pelo menos na concepção tradicional, escapa à jurisdição da gramática."

Desse modo, poder-se-á garantir uma atividade de reflexão sobre a língua, mas é preciso deixar claro que essas atividades a que estamos nos referindo são epilingüísticas, ou seja, estão voltadas para o uso da língua. É preciso não confundir com as atividades metalingüisticas, dispensáveis em nossa proposta, em que se faz uma descrição e uma análise, através da categorização e sistematização dos elementos lingüísticos. As atividades epilingüisticas, relacionadas com o uso efetivo da língua no texto, poderão versar sobre: natureza das frases utilizadas, tipos de palavras e expressões, estratégias discursivas, 
recursos estilísticos, emprego de sinônimos, etc. A esse propósito convém lembrar estas palavras de FRANCHI (1987, p. 20):

"Interessa pouco descobrir a melhor definição de substantivo ou de sujeito ou do que quer que seja. (...) Mas interessa, e muito, levar os alunos a operar sobre a linguagem, rever e transformar seus textos, perceber nesse trabalho a riqueza das formas lingüísticas disponíveis para suas mais diversas opções."

\subsubsection{A "gramática do texto"}

É igualmente problemática a posição de certos professores que sugerem a adoção de uma "gramática do texto" no ensino do português. Essa gramática do texto consistiria no seguinte: ao se estudar um texto, toda vez que aparecer um fenômeno gramatical relevante, este deverá ser explicado e analisado. Em discordância com esse expediente metodológico, pode-se argumentar o seguinte: o que deve ser considerado um fenômeno gramatical relevante? Qual é o critério para determinar quais os fenômenos lingüísticos que devem ser analisados? Tal atitude não poderia fazer o professor retornar a uma gramatiquice sem fim? Esses, contudo, não parecem ser os problemas mais graves. O problema mais grave consiste no perigo de que esse método se torne uma verdadeira "salada gramatical", como passamos a demonstrar no parágrafo que se segue. Antes, porém, convém lembrar que, ainda que o propósito do professor seja o de explicitar os fenômenos lingüísticos que são relevantes para a compreensão e exploração do texto, parece haver aí dois equívocos.

Em primeiro lugar, é preciso considerar que para a explicitação desses fatos gramaticais é necessário que o aluno tenha um domínio prévio de noções gramaticais, o que ele, via de regra, não tem. Para que o professor fale de voz passiva, oração subordinada, sujeito indeterminado, verbo de ligação, etc., é preciso que o aluno tenha um conhecimento anterior do assunto ou, caso contrário, o professor deverá ensinar esses conteúdos gramaticais. Ora, isso significa cair no estudo da gramática pura, o que é, como sabemos, condenável. 
Em segundo lugar, admitindo-se que esse conhecimento prévio não seja importante, que os fatos gramaticais possam ser avaliados à medida que aparecem no texto, corre-se o risco, como dizíamos, de que esse tipo de estudo se torne uma verdadeira "salada gramatical", em que, depois de se realçar um emprego interessante da voz passiva, parte-se logo em seguida para uma explicação de um caso de colocação pronominal, seguida de uma regência verbal original, que, por sua vez, vai desaguar em um emprego estilístico de um verbo defectivo, etc., etc., etc. Desse modo o aluno nunca terá uma noção de conjunto da gramática, nunca perceberá a importância do conceito de estrutura, de oposição, de solidariedade das partes, etc. (no caso de o professor achar que o estudo da gramática é importante). Ora, por ser um tratado, um estudo, uma exposição lógica de dados e de fatos - assim como o são a Biologia, a Física e a Geografia, por exemplo - a gramática é, por definição, sistemática. É o que a esse respeito afirma FRANCHI (1987, p. 8): “...quanto à gramática, uma tal de gramática assistemática; há certamente uma contradição nos termos”.

\subsubsection{A necessidade do estudo da gramática por causa dos vestibulares, concursos públicos, programas das escolas, secretarias de educação e planos nacionais de ensino.}

Há certas pessoas que defendem o estudo da gramática nas escolas pelo fato de ser ela exigida nos vestibulares, concursos públicos, programas de escolas, etc. Contra essa postura, apresentamos os seguintes argumentos:

a - Os vestibulares nas grandes universidades, principalmente nas públicas, têm exigido, cada vez menos, questões relacionadas com a gramática. Como se sabe, essas universidades, devido ao seu inegável prestígio, têm sido as balizadoras que norteiam e orientam os exames vestibulares das instituições particulares. Sem se esquecer do conhecimento objetivo, observa-se que, nos últimos tempos, o que tem sido exigido do candidato ao curso superior está muito mais relacionado com a sua capacidade de 
reflexão, raciocínio e crítica, cobrando-se dele uma postura avaliativa perante os mais diversos problemas. Com relação ao Português, o que se espera dele é a capacidade de acesso à informação - indispensável no mundo contemporâneo -, através da interpretação dos mais variados tipos de texto, bem como o conhecimento de algumas modalidades de língua e o domínio da variante reconhecida como padrão.

b - Com relação aos concursos públicos, é bem verdade que ainda é possível encontrar neste País certos órgãos e instituições - do tipo, assembléia legislativa, tribunal de contas, polícia federal - que insistem na idéia de que saber português é decorar qual é o feminino de cupim, o coletivo de borboleta ou ser capaz de classificar uma oração como sendo uma subordinada substantiva completiva nominal reduzida de gerúndio. O que parece estar acontecendo é que funcionários burocráticos desses órgãos, formados em Letras ou em Direito há quarenta anos - ou, às vezes nem formados - são convocados pelas respectivas chefias para elaborar a prova de Português, e o primeiro modelo que lhes vem à mente são aqueles tipos de questão em que se exigia uma gramatiquice hoje completamente ultrapassada. A pergunta que se deve fazer é: são esses burocratas que devem orientar a política do ensino do Português ou somos nós, professores da língua materna, com os nossos estudos, discussões, reflexões, com os nossos trabalhos escritos e comunicações, que devemos estabelecer as bases, os princípios e os parâmetros que nortearão o ensino do idioma nacional? Na verdade, temos que lutar pela mudança dessa situação e, ainda que muito vagarosamente, é possível observar algumas modificações nesse sentido. Como afirma BAGNO (2000b, p. 121), "cabe a nós, professores, pressionar pelos meios de que dispomos - associações profissionais, sindicatos, cartas à imprensa - para que as provas de concursos sejam elaboradas de outra maneira, trocando as velhas concepções de língua por novas". 
c - Com relação aos programas das escolas (geralmente estabelecidos pelos coordenadores de área), aos programas elaborados pelas secretarias de educação, aos planos nacionais de ensino, bem como aos conteúdos gramaticais apresentados pelos livros didáticos, é preciso reconhecer que temos assistido a uma mudança de postura em certos setores, que estão passando a se preocupar basicamente com o desempenho lingüístico do aluno, embora esses setores, é verdade, não consigam se ver totalmente livres do jugo da gramática. Lembremo-nos também de que há uma pressão generalizada da sociedade, através dos pais de alunos, dos profissionais liberais, das pessoas mais idosas e dos intelectuais passadistas e ultrapassados, no sentido de que seja dada gramática em sala de aula, pois, caso contrário, a Língua Portuguesa, um dos símbolos da nacionalidade, não estaria sendo estudada nas escolas. Ora, o que se nota aqui é, mais uma vez, uma confusão entre estudar a língua e estudar a gramática. Embora o professor de Português tenha que se preocupar com esse tipo de problema e seja obrigado a aprender a se defender desse tipo de pressão, devemos dizer que, neste trabalho, estamos preocupados com uma outra questão - ligada ao que acabamos de expor, não há dúvida - mas que apresenta uma natureza diversa dos problemas aqui apresentados: estamos preocupados muito mais com a convicção que o professor deve ter com relação a esses assuntos do que com os fatos em si. Se ele estiver convicto de determinadas posições, certamente ela saberá se defender de influências nefastas no ensino de Português.

\subsection{A real utilidade do estudo da gramática}

Antes de terminarmos este item, gostaríamos de perguntar: afinal, o estudo da gramática tem alguma utilidade? Por mais paradoxal que possa parecer, diremos que sim, e muita. Apesar de tudo o que dissemos, defendemos a idéia de que a gramática deve 
ser estudada profundamente no curso superior de Letras (e apenas nesse curso superior), na disciplina intitulada Lingüística, que é a instância adequada em que se faz o estudo científico da linguagem humana. Algumas pessoas poderiam estranhar que o estudo da gramática só seja feito no curso superior de Letras. Em vez de se constituir uma desvantagem, trata-se de um ponto positivo para o conhecimento da língua, pois o aluno chega ao curso superior sem os vícios e os preconceitos de um estudo mal feito na escola fundamental e média. Mesmo assim, poder-se-ia argumentar que os quatro anos do curso superior de Letras não são suficientes para o estudo da gramática, uma vez que se parte da estaca zero. Mas isso não é o que se dá com o curso de Direito, de Odontologia ou de Economia, em que também se parte da estaca zero?

O estudo da gramática se faz necessário na escola de $3^{\text {o }}$ grau por três motivos básicos:

$1^{\text {o }}$ - É no curso superior de Letras que têm início as pesquisas lingüísticas, que serão a base para o estudo científico da linguagem humana. Essas pesquisas são indispensáveis para o conhecimento da língua portuguesa e das línguas de um modo geral, bem como para o conhecimento do próprio Homem, já que a língua é o apanágio do Homem e constitui um dos seus principais atributos. Geralmente, essas pesquisas lingüísticas têm continuidade no nível de mestrado e doutorado e ocuparão toda a vida de um pesquisador.

$2^{\mathrm{o}}$ - Como veremos no item 3 deste trabalho, o professor de Português deverá ter uma visão geral da gramática portuguesa, para poder dividir os seus itens pelas diversas séries do nível fundamental. O professor programará, por exemplo, que o emprego das conjunções coordenativas se dará na 5ª série, a concordância verbal na 6 ${ }^{\underline{a}}$, o emprego do verbo haver na 6 ${ }^{\underline{a}}$, e assim por diante. Como se verá oportunamente, tudo isso se dará na prática, no exercício efetivo da língua, através de treinamento especial, jamais através do estudo da gramática explícita. 
$3^{\circ}$ - Muitas vezes, na resolução de um problema que aparece na redação de um aluno, o professor precisará de um conhecimento mais profundo da língua. Suponhamos que o professor depare com uma construção como esta: "- Separa-se os grãos". Baseado em quê irá o professor corrigir essa frase ou não? Quais serão os argumentos utilizados pelo professor? Ao aluno só interessa saber como se usa, mas ao professor interessa o porquê do problema.

Para entendermos melhor a questão que acabamos de expor, é interessante comparar a condição do professor de Português com a condição do médico. O médico dedica cinco, seis ou sete anos aos estudos que servirão de base para o exercício de sua profissão, mas, na maioria das vezes, em uma consulta, esse profissional se limita a requisitar uns exames e a prescrever alguns medicamentos. Além disso, o médico poderá atender o paciente em dez ou quinze minutos, como costuma acontecer no serviço público e em alguns dos atuais planos de saúde. Mas para atender o paciente, ou seja, na prática da sua profissão, o médico precisará de uma retaguarda teórica que dará sustentação ao exercício da Medicina.

E como fica a questão do ensino de português no curso médio? Gostaríamos apenas de fazer a seguinte pergunta: se o aluno pode sair da oitava série em condições satisfatórias de ler e redigir textos em português padrão - afinal é esse o objetivo principal do curso fundamental -, qual seria a real utilidade do estudo da gramática no curso médio? Parece-nos que nenhuma. No curso médio, o aluno deve continuar praticando a produção da leitura e a produção da escrita, sempre com a orientação do professor de Português, mas deve voltar a sua atenção para o estudo exclusivo da literatura. Mas essa é uma questão que escapa aos objetivos deste artigo.

\section{A PRÁTICA DO ENSINO DE PORTUGUÊS}

Como dissemos na introdução deste trabalho, não basta dizer simplesmente, por exemplo, que o ensino da gramática é dispensável ou prejudicial ao aluno. Não basta apontar os vícios do ensino 
gramatical, uma tarefa relativamente fácil hoje em dia, e que tem sido feita por diversos autores. O difícil é apresentar uma proposta concreta, funcional, viável, inteligente e convincente. Já dissemos que a proposta de o aluno passar oito anos do nível fundamental "apenas" interpretando textos e fazendo redações é ingênua, ineficaz e contraproducente, embora reconheçamos, é evidente, a importância dessa atividade. Além da leitura e produção de texto, estamos propondo que o ensino de português deve contar também com uma atividade de fundamental importância, a que daremos a denominação de EXERCÍCIOS EM LÍNGUA PADRÃO (ELP's). Essa atividade dará à nossa proposta essa organização e sistematicidade a que nos referimos. Dessa maneira, uma LIÇÃO DE PORTUGUÊS, que servirá de unidade básica para o TREINAMENTO EM LÍNGUA PADRÃO (TLP), deverá constar de três módulos:

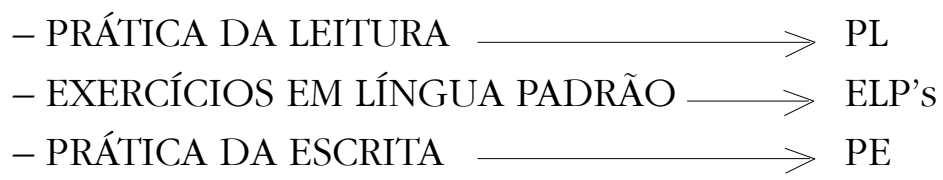

\subsection{O treinamento em língua padrão}

Sintetizando o que dissemos neste trabalho até aqui, podemos dizer que a nossa preocupação está voltada para o ensino do Português como um todo. Nosso método pretende, portanto, ser orgânico e não, um emaranhado de condenações e de sugestões, como se encontra em muitos artigos e livros que tratam do assunto. Por motivos diversos, estamos fixando a nossa atenção na questão do ensino da língua padrão. Daqui por diante, estaremos nos preocupando especialmente com o ELP, embora, mais uma vez, reconheçamos a fundamental importância da PL e da PE. Isso se torna necessário, porque, na verdade, o ELP, além de ser a novidade no método que estamos propondo, é a argamassa que impregnará a nossa proposta de organicidade. Para facilitar a sua identificação - como dissemos na Introdução deste trabalho - estamos dando a essa proposta a denominação de MÉTODO GNM (Gramática: Nunca Mais). 


\subsection{As bases teóricas do TLP}

Sabemos que as concepções teóricas que formam o arcabouço filosófico da Gramática Gerativa são unânimes em afirmar que todo indivíduo nasce com uma predisposição intuitiva, natural e biológica para a aquisição de uma língua (CHOMSKY, 1965). A faculdade de linguagem é, portanto, um dom natural: do mesmo modo como aprende a caminhar, a respirar e a dormir, o ser humano fatalmente irá aprender a falar. Mas a língua que a criança vai aprender a falar será a língua da comunidade em que ela estiver inserida. Sabemos que um recémnascido brasileiro, por exemplo, se for levado para a Alemanha, irá não só aprender a falar alemão, como também a "pensar em alemão". Este é um dado óbvio e que servirá como aporte para o método que estamos propondo. Quando da aquisição da linguagem, a criança, além de possuir essa predisposição natural pelo uso da linguagem, passa por um tipo especial de treinamento em uma língua específica, através do contato com os pais, irmãos, babás, amigos, etc. Esse treinamento apresenta as seguintes características:

- é feito de maneira intuitiva;

- é feito de maneira intensiva;

- é feito de maneira assistemática;

- é um treinamento que conta com um método extremamente eficiente, porque, além de repetitivo, é muito motivado, pois a criança precisa pensar e se comunicar em uma determinada língua;

- é feito sem o auxílio de qualquer gramática explícita.

Do mesmo modo como uma criança adquire uma língua natural através de internalização e de um tipo especial de treinamento, essa mesma criança, ao entrar para a Escola, precisa também passar por um treinamento para dominar uma outra modalidade de língua, a língua padrão, com algumas características diferentes de sua língua natural. Como afirma LUFT (1993, p. 103): "O objetivo, na escola, é ensinar a (gramática da) língua culta? Pois então, o racional, o sensato, 
e o inteligente, é propiciar isso mediante a exposição do aluno ao funcionamento da língua culta: falas, gravações, textos orais e escritos, etc." Com o processo de aquisição da modalidade culta da língua, dá-se o mesmo processo de aperfeiçoamento e tecnização de certas atividades naturais do homem, como correr, saltar e cantar. Para se correr ou saltar com finalidades olímpicas ou para se cantar profissionalmente, é necessário passar por um treinamento especial. No caso da aquisição da língua padrão, esse treinamento, que estamos denominando de TLP, é diferente do treinamento para a aquisição da língua natural por três motivos básicos:

- o tipo de língua que a criança passa a dominar não é natural, ou seja, apresenta características artificiais e convencionais, o que dificulta o seu aprendizado;

- a motivação para a aquisição da língua padrão é bem reduzida, comparando-se com a motivação para a aquisição da língua natural, já que esta é uma necessidade imediata do indivíduo e aquela, não;

- a freqüência de treinamento é também diferente: a criança é bombardeada por todos os lados pela língua natural, ao passo que o TLP é feito, via de regra, na escola, mesmo assim em ocasiões específicas.

Respeitadas as diferenças entre a aquisição da língua natural e a modalidade culta da língua, cumpre observar o seguinte: a tarefa de adquirir a língua natural é bem mais complexa do que a tarefa de dominar a modalidade padrão da língua. No primeiro caso, estamos aprendendo uma língua e, no segundo, estamos apenas adaptando-a a uma nova circunstância. Se não há necessidade de aprender gramática explícita para adquirir uma língua, por que haveria necessidade de aprender gramática para adaptar a língua a uma nova circunstância? Se o treinamento para a aquisição da língua natural é eficiente, como dissemos acima, é necessário tornar o treinamento para a aquisição da modalidade culta da língua também eficiente. 
Por causa dos motivos expostos, é necessário que o TLP seja altamente eficiente. Foi proposto que, "ao final da $8^{\mathbf{a}}$ série, o aluno deve dominar o dialeto padrão." Sabemos que o treinamento em língua natural é feito em pouco tempo. Com cinco anos, a criança já domina as estruturas básicas da língua, ou seja, já fala português, o que pode ser considerado uma tarefa extremamente difícil. Basta pensar no fato de como é difícil sermos fluentes em inglês, alemão ou russo, do mesmo modo como uma criança de cinco anos é fluente em português. Mesmo considerando a eficácia do treinamento em língua natural em face do TLP, é impressionante constatar a ineficiência de grande parte do ensino de português atual, que não consegue, em oito anos, dotar o aluno da capacidade de escrever, de maneira correta e orgânica, uma ou duas páginas em português padrão.

Se a criança, aos cinco anos, já faz uso das estruturas básicas da língua (como dissemos no parágrafo anterior), ou seja, se já possui ou domina, ainda que intuitivamente, uma "gramática subjacente ou internalizada”, por que essa criança precisa aprender gramática na Escola? Não faz sentido, portanto, ensinar gramática na Escola: o que deve ser feito é uma adaptação da língua que ela já domina às diversas modalidades que são levadas em consideração nas aulas de Português, principalmente a modalidade padrão.

Ao entrar para a Escola, a criança desenvolve de maneira acentuada a sua capacidade de raciocinar (incluir, excluir, concluir, comparar, relacionar, etc.), através do contato com os professores, diretores, orientadores, supervisores, funcionários, colegas e principalmente com a imersão nos conteúdos das diversas disciplinas. O aluno começa também a tomar contato de maneira mais constante e funcional com a língua padrão, não apenas através das aulas de Português, mas também através dos textos de Geografia, História, Ciências, etc. Tem início então para a criança o TLP, que é feito de maneira assistemática pelos docentes das diversas disciplinas, através da leitura de textos. Compete ao professor de Português organizar esse treinamento de maneira eficaz e sistemática. Surge então o TLP propriamente dito, que é dado nas aulas de Português, da maneira como proporemos adiante. 
Antes porém, é preciso destacar e fixar o seguinte ponto de vista: língua é uso, qualquer que seja a sua modalidade. E isso se aplica, também, evidentemente, à modalidade culta da língua. Ela só existe efetivamente em processo. Como afirma RAMOS (1997, p. 20), "é usando que se aprende a usar uma língua." A tarefa de descrever e/ ou desmontar as palavras e frases da língua é específica dos gramáticos e lingüistas. Observem-se estas palavras de DILLINGER (1995, p. 38): "supor que descrever palavras e frases ajuda o aluno a comunicar é como pensar que descrever as partes da bicicleta ajuda a criança a andar de bicicleta. É uma posição insustentável. O ensino da gramática é irrelevante".

Do exposto, é preciso traçar uma linha clara que distinga o processo de aquisição de uma língua natural do processo de aprendizagem da língua padrão. Embora estreitamente relacionados, já que, no fundo, trata-se da aquisição de modalidades da mesma língua, é preciso, no entanto, apontar algumas diferenças marcantes, uma vez que o primeiro tipo de aquisição é natural e o segundo, artificial. Como afirma Ernst Cassirer (apud ALVES, 1987, p. 59), “... a dificuldade real está menos na aprendizagem de uma nova linguagem que no esquecimento da linguagem anterior".

\section{A PRÁTICA DO ENSINO DE PORTUGUÊS}

Chegamos ao centro de nossas preocupações, que é a aplicação dos ELP's na prática da sala de aula. Como dissemos anteriormente, "do mesmo modo como a aquisição da língua natural se dá através de treinamento, o domínio da língua padrão se dá através do TLP” e, mais especificamente, dos ELP's.

Na prática da sala de aula, em que consistem os ELP's?

Todo professor de Português sabe que o aluno, para poder se expressar em norma culta, precisa ter o domínio de certas especificidades que caracterizam essa modalidade de língua. Em outras palavras, os alunos precisam passar por treinamentos relacionados com o emprego dessas especificidades, porque, como vimos, língua 
é uso. Muitos professores já fazem isso com o auxílio da gramática. Defendemos, no entanto - por razões amplamente discutidas anteriormente -, a idéia de que esse treinamento deve ser feito sem o auxílio da gramática, mas de maneira organizada e intensiva. Como isso é possível?

Eis alguns itens do uso da língua padrão que devem constituir objeto de treinamento:

- concordância verbal

- concordância nominal

- regência verbal

- emprego de pronomes

- colocação de pronomes

- emprego do verbo haver

- flexão nominal e verbal

- emprego da voz passiva pronominal, etc.

Itens de treinamento, como os acima mencionados, devem ser distribuídos pelas diversas séries do curso fundamental. Essa distribuição, porém, deve ser feita sem que o aluno tome conhecimento dela e das etiquetas identificadoras desses itens (concordância verbal, concordância nominal, regência verbal, etc.). Neste ponto de nossas considerações, alguns colegas poderão dizer:

- Enfim, o autor deste trabalho se revelou e mostrou a importância de se estudar a gramática!

É preciso lembrar no entanto que;

"A gramática é a descrição e/ou interpretação dos fenômenos lingüísticos". Ora, o professor de Português não fará qualquer descrição e/ou interpretação dos fenômenos lingüísticos e não usará terminologia gramatical, mas se preocupará apenas com o emprego e o treinamento da língua padrão.

À guisa de sugestão, apresentamos o quadro abaixo, que poderá ser aplicado a partir da $3^{\underline{a}}$ série (as duas primeiras séries serão dedicadas à aquisição da escrita e ao treino ortográfico). O ideal é 
que este quadro seja bem especificado, mas por questões de tempo e de espaço, não podemos fazer isso neste artigo.

Observe, caro Colega, que este quadro é apenas uma sugestão. É claro que transposições, acréscimos e cortes podem ser feitos.

\section{$3^{a}$ série}

\begin{tabular}{|c|c|c|c|}
\hline \multirow[t]{3}{*}{$1^{\circ}$ semestre } & $1^{\circ}$ bimestre & $\begin{array}{l}1^{\mathrm{o}} \text { mês } \\
2^{\mathrm{o}} \text { mês }\end{array}$ & $\begin{array}{l}\text { número do substantivo } \\
\text { número do adjetivo }\end{array}$ \\
\hline & $2^{\circ}$ bimestre & $1^{\circ}$ mês & gênero do substantivo \\
\hline & & $2^{\mathrm{o}}$ mês & gênero do adjetivo \\
\hline \multirow[t]{4}{*}{$2^{\mathrm{o}}$ semestre } & $3^{\circ}$ bimestre & $1^{\circ}$ mês & grau do substantivo \\
\hline & & $2^{\mathrm{o}}$ mês & grau do adjetivo \\
\hline & $4^{\circ}$ bimestre & $1^{\circ}$ mês & emprego dos verbos regulares \\
\hline & & $2^{\mathrm{o}}$ mês & $\begin{array}{l}\text { emprego dos verbos irregulares mais } \\
\text { comuns }\end{array}$ \\
\hline
\end{tabular}

\section{4⿳a série}

$1^{\underline{0}}$ semestre $1^{\circ}$ bimestre $1^{\circ}$ mês

emprego dos verbos irregulares (contin.) $2^{\circ}$ mês emprego dos verbos irregulares (contin.)

$2^{\circ}$ bimestre $1^{\circ}$ mês concordância nominal (iniciação)

$2^{\circ}$ semestre $\quad 3^{\circ}$ bimestre $1^{\circ}$ mês concordância verbal (iniciação) emprego da crase treinamento em pontuação $4^{\circ}$ bimestre $1^{\circ}$ mês emprego de numerais, advérbios e preposições

$2^{\circ}$ mês emprego de pronomes (iniciação)

\section{5ª série}

$1^{\circ}$ semestre $1^{\circ}$ bimestre $1^{\circ}$ mês

treino de estruturas mais elaboradas orações coordenadas - em especial, emprego de conjunções menos usadas, como, porém, todavia, contudo, no entanto, ora ... ora, quer ... quer, seja ... seja, portanto, por conseguinte, pois, que (conclusiva), etc.

$2^{\circ}$ mês idem

$2^{\circ}$ bimestre $1^{\circ}$ mês treino de estruturas mais elaboradas orações subordinadas, em especial, emprego de conjunções subordinativas menos usadas, como, porquanto, uma vez que, desde que, conquanto, posto que, se bem que, consoante, a fim de que, etc.) 


$\begin{array}{ccll}2^{\circ} \text { semestre } & 3^{\circ} \text { bimestre } & \begin{array}{l}2^{\circ} \text { mês } \\ 1^{\circ} \text { mês }\end{array} & \begin{array}{l}\text { idem } \\ \text { regência nominal (iniciação) }\end{array} \\ & 2^{\circ} \text { mês } & \begin{array}{l}\text { regência verbal (iniciação) } \\ 4^{o} \text { bimestre }\end{array} 1^{\circ} \text { mês } & \text { emprego de pronomes (iniciação) } \\ & 2^{\circ} \text { mês } & \text { idem }\end{array}$

\section{6⿳亠丷厂 série}

$1^{\mathrm{O}}$ semestre $1^{\mathrm{O}}$ bimestre $1^{\mathrm{o}}$ mês

concordância nominal

$2^{\mathrm{o}}$ mês

idem

$2^{\mathrm{o}}$ bimestre $1^{\mathrm{o}}$ mês

concordância verbal

$2^{\circ}$ mês

idem

$2^{\circ}$ semestre $\quad 3^{\circ}$ bimestre $1^{\circ}$ mês

emprego de pronomes pessoais retos e oblíquos

$2^{\mathrm{o}}$ mês

emprego dos pronomes de tratamento

4 bimestre $1^{\circ}$ mês

emprego dos pronomes demonstrativos

$2^{\circ}$ mês

emprego dos pronomes indefinidos e

relativos

\section{7ª série}

$1^{\mathrm{o}}$ semestre $\quad 1^{\mathrm{o}}$ bimestre $1^{\mathrm{o}}$ mês

\section{regência verbal}

$2^{\mathrm{o}}$ mês

regência verbal e emprego de pronomes

(p. ex., emprego de o e lhe)

$2^{\underline{o}}$ bimestre $1^{\circ}$ mês colocação de pronomes

$2^{\mathrm{o}}$ mês

idem

$2^{2}$ semestre $\quad 3^{\circ}$ bimestre $1^{\circ}$ mês emprego do verbo haver $2^{\mathrm{o}}$ mês idem

$4^{\circ}$ bimestre $1^{\circ}$ mês emprego dos verbos impessoais $2^{\mathrm{o}}$ mês idem

\section{8 série}

$1^{\mathrm{o}}$ semestre $1^{\mathrm{o}}$ bimestre $1^{\mathrm{o}}$ mês $2^{\circ}$ mês

regência verbal com pronomes relativos

$2^{\mathrm{o}}$ bimestre $1^{\mathrm{o}}$ mês idem $2^{\mathrm{o}}$ mês concordância verbal: casos especiais

$2^{\circ}$ semestre $\quad 1^{\circ}$ bimestre $1^{\circ}$ mês idem $2^{\mathrm{o}}$ mês emprego do infinitivo idem

$2^{\mathrm{o}}$ bimestre $1^{\mathrm{o}}$ mês emprego da voz passiva pronominal $2^{\mathrm{o}}$ mês idem 
Tomemos como exemplo de ELP o item de treinamento concordância verbal, que começa a ser dado na $4^{\underline{a}}$ série e é aprofundado na $6^{\underline{a}}$ e $8^{\underline{a}}$ séries. Na verdade, a distribuição de um determinado item de treinamento por séries distintas é aconselhável por dois motivos: $1^{\circ}$ ) permite uma maior dosagem do problema, começando por casos simples e terminando pela prática de casos especiais; $2^{\circ}$ ) evita que se pratique um item, digamos, na $5^{\underline{a}}$ série, e que esse item nunca mais seja objeto de treinamento.

Sobre o "espírito" que deve nortear a elaboração dos exercícios de treinamento, tais como estamos propondo, gostaríamos de deixar claro o seguinte:

A - Como dissemos anteriormente, ao entrar para a Escola, o aluno já fala português, ou seja, já domina as estruturas básicas da língua. Devem ser evitados, portanto, exercícios com palavras, expressões e estruturas que ele já conhece, para que a prática não se torne repetitiva e cansativa. Não são dados exercícios do tipo o pato está cansado/a pata está cansada, nem são pedidos os femininos de galo, rei ou príncipe, os quais os alunos já conhece pelas estórias infantis e pelas leituras realizadas nas primeiras séries do ciclo fundamental. Os ELP's devem se constituir em uma espécie de desafio ao aluno. É como se perguntássemos a ele constantemente: você já domina o português, mas você sabe usar o dialeto padrão?

B - Nestes exercícios não se trabalha com "palavróides", ou seja, com falsas palavras. Estamos chamando de "palavróides" aquelas que só aparecem nas gramáticas tradicionais, com o objetivo de ilustrar determinadas regras, como por exemplo: o voga/a voga, felá/felaina, píton/pitonisa, o abusão/a abusão, ladravaz, medicastro, apropinquar-se, obviar, etc. Trata-se de arcaísmos, ou de palavras muito pouco usadas na língua, mesmo no dialeto padrão. É preciso reconhecer, no entanto, que vocábulos, expressões e estruturas pertencentes ao dialeto culto contemporâneo devem fazer parte dos exercícios. 
C - Deve-se tomar cuidado para que os ELP's não sejam feitos exclusivamente com exercícios estruturais. Para tanto, deve-se variar os tipos de exercícios, evitando-se repetições desnecessárias e cansativas.

D - Na aplicação dos ELP's, é indispensável o acompanhamento e a orientação do Professor de Português, realçando determinado aspecto, explicando o emprego de tal expressão, sem necessidade alguma de se explicitar a teoria gramatical. Alguns poucos ou mesmo raros termos da gramática poderão ser usados, desde que: a) não haja, por parte do professor, cobrança com relação à definição, classificação ou identificação desses termos, não devendo haver, portanto, em sala de aula, qualquer trabalho de análise metalingüística; b) sejam termos comuns usados pelas pessoas em geral e não demandem um conhecimento técnico específico; são palavras como: frase, palavra, singular, plural, masculino, feminino, maiúscula, minúscula, verbo, coletivo, etc., cujos significados qualquer pessoa pode saber, sem estudar gramática.

E - É preciso considerar que os ELP's têm como objetivo levar o aluno a dominar certas características da língua padrão, que ele normalmente não conhece. Convém lembrar que esse mesmo aluno é exposto todo dia a modelos de língua padrão, não só nas aulas de português - com a produção da leitura -, como também nas aulas de outras disciplinas, bem como no contato com outros textos dentro e fora da Escola (jornais, revistas, livros, circulares, instruções, etc.). Possíveis lacunas no aprendizado da língua padrão através dos ELP's são preenchidas pela exposição constante a esses tipos de texto.

F - Como o objetivo dos ELP's é o aprendizado da língua padrão, foram evitadas palavras, expressões ou construções da linguagem coloquial na elaboração desses exercícios. Apesar de se encontrarem algumas exceções, os exercícios apresentam-se, via de regra, em linguagem formal, como foi definido no Projeto GNM. 
G - Por último, mas como um dos itens mais importantes dessa postura que deve nortear a confecção e a aplicação dos ELP's, observe-se que eles são, praticamente, auto-explicativos. Isso se deve ao fato de que eles aproveitam o conhecimento prévio que os alunos já têm do português, ou seja, o aluno que entra para a Escola já fala português, já conhece a sua língua, já possui uma gramática subjacente, como preconiza a teoria gerativa. Como dissemos anteriormente, na Escola faz-se uma adaptação da língua que o aluno já possui a uma variante pouco utilizada por ele, a chamada língua padrão. Com os ELP's, o aluno parte diretamente para a prática, para o emprego, para a ação, evitandose a exposição teórica fastidiosa, cansativa e contraproducente que o professor é obrigado a fazer quando se propõe a ensinar "a gramática pela gramática” em sala de aula.

Em seguida apresentamos algumas sugestões de exercícios, que poderão servir de modelo para posteriores desdobramentos por parte dos professores.

\section{A - Emprego de a/à, as/às (crase)}

Recomendações ao professor:

Ensino do emprego do acento indicador da crase por meio da substituição de um substantivo feminino por um substantivo masculino. O professor mostrará ao aluno que, ocorrendo ao diante da palavra masculina, $a$ recebe o acento da crase. Quase todos os problemas da crase, como se verá adiante, podem ser resolvidos através desse expediente. Um dos motivos por que a maioria das pessoas não sabe usar a crase é porque esse assunto é ensinado com o auxílio da gramática (crase é a contração da preposição $a$ com o artigo $a$; dá-se a crase porque o verbo rege a preposição $a$ ). Como são pouquíssimas as pessoas que sabem gramática... 
Observe:

IREMOS A PRAIA.

IREMOS À PRAIA.

IREMOS AO MUSEU.

APRESENTEI-ME A DIRETORA. APRESENTEI-ME À DIRETORA. APRESENTEI-ME AO DIRETOR.

OBEDEÇO AS LEIS DE DEUS. OBEDEÇO ÀS LEIS DE DEUS. OBEDEÇO AOS MEUS PAIS.

DEDICO-ME AS ARTES. DEDICO-ME ÀS ARTES.

DEDICO-ME AOS ESTUDOS.

Siga os modelos apresentados:

1 - Ontem fui a praia.

Ontem fui ao cinema.

2 - O diretor referiu-se a aluna.

O diretor referiu-se ao aluno.

3- Recorreram a justiça.

Recorreram ao juiz.

4 - Cedi o livro a professora.

Cedi o livro professor.

5 - Ele compareceu as reuniões.

Ele compareceu ensaios.

\section{B - Concordância entre as palavras na frase:}

a - Nas frases abaixo, os termos sublinhados referem-se a palavras e expressões marcadas com um balão:

Em abril, os operários resolveram suspender a greve.

$\mathrm{Na}$ aula de inglês, surgiram muitas reclamações

Proceda da mesma maneira com as frases abaixo:

1. As sombras envolvem a cidade.

2. As estrelas brilham no céu de Diamantina. 
3. No coração das mães crescem todos esses pensamentos.

4. Isto não me agrada.

5. Foi rápido o regresso do amigo.

b - Complete as frases abaixo com as palavras entre parênteses, fazendo as devidas modificações:

1. Durante todo o inverno, os animais se na floresta (esconder / passado).

2 . (caminhar / presente). à frente das escolas o porta-bandeira

3. Neste lago, não (existir / presente).

4. Às vezes fatos que parecem impossíveis (acontecer / presente).

5. Aqui outrora plantas aquáticas

.

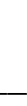

e).


Grupo a: herói, tatu, campeã, nó, degrau, troféu, flautim, atum

Grupo b: faquir, açúcar, rês, mal, cônsul, xadrez

Grupo c: níquel, farol, sol, álcool, réptil, projétil, funil, barril

Grupo d: tubarão, vulcão, capelão, escrivão, cidadão, pagão

Grupo e: oásis, cais, alferes, tórax, atlas

O caro Colega poderá observar que alguns exercícios, como o citado acima, requerem por parte dos alunos algum tipo de pesquisa. O professor poderá indicar, portanto, algum livro de consulta que apresente os plurais, os femininos, os coletivos, as conjugações verbais, etc. Poderá indicar também o uso do dicionário. De nossa parte, achamos desaconselhável a consulta às gramáticas tradicionais por parte dos alunos. De fato, para se consultar uma gramática, é necessário saber gramática, do mesmo modo como para se consultar o Código Civil é necessário saber Direito Civil. Experimente o caro Colega pedir aos seus alunos para localizar nas gramáticas o emprego do acento indicador da crase. É uma das tarefas mais difíceis que existem!

\section{D - Emprego de conjunções subordinativas}

Substitua as seqüências sublinhadas por outras de igual sentido, de acordo com o modelo (fazendo as modificações necessárias):

1 - Como estivesse de luto, não nos recebeu.

porquanto: Não nos recebeu, porquanto estivesse de luto.

uma vez que:

já que:

pois:

2 - Célia vestia-se bem, embora fosse pobre.

ainda que :

conquanto:

mesmo que:

posto que:

se bem que :

em que (pese) : 
3 - Ficaremos sentidos, a menos que você venha.

se:

salvo se:

contanto que:

caso:

desde que:

a não ser que:

\section{E - Emprego de pronomes pessoais retos e oblíquos}

Modelo: Este presente é para mim.

Este presente é para eu abrir.

Siga o modelo:

1 - Este livro é para mim.

2 - Esta lembrança é para mim.

3 - Este perfume é para mim.

4 - Aquele anel é para mim.

5-Meu namorado deu este presente para mim.

\section{F - Colocação de pronomes}

$\mathrm{Na}$ língua padrão, não se iniciam frases com as palavras me, te, se, the, nos e vos. Corrija as frases abaixo, de acordo com o modelo:

Se sabe que a Terra é redonda.

Sabe-se que a Terra é redonda.

1 - Me acusaram de ingrato!

2 - Te argüiram em condições precárias.

3 - Se comenta que o candidato irá renunciar.

4 - Se extraiu muito ouro das montanhas de Minas.

5 - Nos disseram que os professores irão se reunir amanhã. 


\section{G - Emprego da voz passiva pronominal}

Observe os modelos:

\begin{tabular}{|c|c|c|c|c|}
\hline Alugam-se & apartamentos & $\Rightarrow$ & Apartamentos & são alugados. \\
\hline Vendem-se & casas & & \begin{tabular}{|l|} 
Casas são ve \\
.
\end{tabular} & ndidas \\
\hline Con & eladeira & & Geladeira é co & isertada \\
\hline
\end{tabular}

Siga o modelo:

$1-$ -se uma lição de português. (preparar)

Uma lição de português foi preparada. -se uma casa de praia em Cabo Frio. (alugar) - se a comida no fogareiro. (esquentar)

$4-$ - se todos os alunos do colégio no pátio. (reunir)

5 - Já não se automóveis como antigamente. (fabricam).

\section{CONCLUSÃO}

O processo de letramento tem início antes da alfabetização, pois a criança, mesmo a menos favorecida socialmente, nasce em uma sociedade letrada, cercada de escrita por todos os lados. Antes de aprender a ler e a escrever, ela entra em contato com essas práticas. Na escola, a criança é alfabetizada e "letrada", mas é no

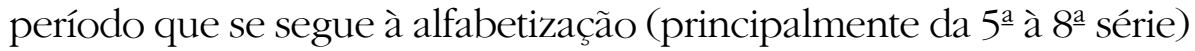
que o professor de Português fica meio perdido e se torna incapaz de promover o verdadeiro letramento social do aluno. Repetindo o pensamento de SOARES (2000, p. 1), citado anteriormente, "letrarse" socialmente significa exercer as práticas sociais de leitura e escrita que circulam na sociedade em que se vive: saber ler e ler jornais, revistas, livros; saber ler e interpretar tabelas, quadros, formulários, 
carteira de trabalho, contas de água, luz, telefone; saber escrever e escrever cartas, bilhetes, telegramas sem dificuldade, saber preencher um formulário, saber redigir um ofício, um requerimento. Para que o aluno "se letre" socialmente, ou seja, para que ele participe de maneira efetiva do mundo da leitura e da escrita que o cerca, é necessário que o professor de Português se compenetre de que (conforme procuramos demonstrar neste artigo): 1 - O objetivo primordial da escola é ensinar o português padrão; 2 - O aprendizado do português padrão deve ser feito sem o estudo da gramática; 3 - Para aprender o português padrão o aluno precisa praticar sistematicamente esse português padrão.

\section{REFERÊNCIAS BIBLIOGRÁFICAS}

ALONSO, Amado; UREÑA, Pedro Henriquez. Gramática castellana. 22. ed. Buenos Aires: Losada, 1964. 2v.

ALVES, Rubem. Conversa para quem gosta de ensinar. São Paulo: Cortez, 1987. AZEREDO, José Carlos de. Entre léxico e gramática: a questão da auxiliaridade verbal. In: VALENTE, André. (Org.) Lingua, Lingüística e Literatura. Rio de Janeiro: EdUERJ, 1998. p. 163-171.

BAGNO, Marcos. Dramática da Língua Portuguesa: tradição gramatical, mídia \& exclusão social. São Paulo: Loyola, 2000.

2000b.

Preconceito lingüístico: o que é, como se faz. 3. ed. São Paulo: Loyola,

BAPTISTA, Maria Elizabeth Motta Zanetti. Gramática. São Paulo: Cortez, 1980. BECHARA, Evanildo. Ensino da gramática. Opressão? Liberdade? São Paulo: Ática, 1985. (Coleção Princípios)

CEGALLA, Domingos Paschoal. Novíssima gramática da Língua Portuguesa. 20. ed. São Paulo: Nacional, 1979.

CHOMSKY, Noam. Aspects of the theory of syntax. Cambridge: The MIT Press, 1965.

CUNHA, Celso. Lingua Portuguesa e realidade brasileira. 7. ed.atualiz. Rio de Janeiro: Tempo Brasileiro, 1977.

; CINTRA, Luís F. Lindley. Nova gramática do Português contemporâneo.

Rio de Janeiro: Nova Fronteira, 1985. 
DARWIN, Charles. Autobiografia: 1809 - 1882. Rio de Janeiro: Contraponto, 2000.

DILLINGER, Mike. O ensino gramatical: uma autópsia. In: SEMANA DE ESTUDOS DE LÍNGUA PORTUGUESA, I, 1993, Belo Horizonte. Belo Horizonte: Departamento de Letras Vernáculas, Faculdade de Letras da UFMG, 1995, v. I, p. 31-65.

FERREIRA, Aurélio Buarque de Holanda. Novo dicionário da Língua Portuguesa. Rio de Janeiro: Nova Fronteira, 1975.

FRANCHI, Carlos. Criatividade e gramática. São Paulo: Secretaria da Educação/ Coordenadoria de Estudos e Normas Pedagógicas, 1987. Mimeografado.

. Mas o que é mesmo "gramática"? Mimeografado.

LIMA, Carlos Henrique Rocha. Gramática normativa da Língua Portuguesa. 15. ed. refund. Rio de Janeiro: José Olympio, 1972.

LUFT, Celso Pedro. Língua e liberdade: por uma nova concepção da língua materna. 2. ed. reform. e ampl. São Paulo: Ática, 1993.

MINISTÉRIO DA EDUCAÇÃO. Parâmetros curriculares nacionais: Língua Portuguesa. 2. ed. Rio de Janeiro: DP \& A, 2000. V.2.

PERINI, Mário A. Para uma nova gramática do Português. São Paulo: Ática, 1985 (Série Princípios)

POSSENTI, Sírio. Por que (não) ensinar gramática na escola. Campinas: ALB/ Mercado de Letras, 1997.

RAMOS, Jânia. O espaço da oralidade na sala de aula. São Paulo: Martins Fontes, 1997.

ROCHA, Luiz Carlos de Assis. Por que ensinar gramática? SEMANA DE ESTUDOS DE LÍNGUA PORTUGUESA, ANAIS, I, v. II, Belo Horizonte: Faculdade de Letras da UFMG, 1979, 19-29.

. Estruturas morfológicas do Português. Belo Horizonte: Ed. UFMG, 1998.

. Norma culta escrita: tentativa de caracterização. In: MENDES, Eliana Amarante de Mendonça; OLIVEIRA, Paulo Motta; BENN-IBLER, Veronika (Org.). Revisitações; edição comemorativa - 30 anos da Faculdade de Letras da UFMG. Belo Horizonte: Faculdade de Letras da UFMG, 1999, pp. 119-142.

. Gramática: nunca mais - o ensino da língua padrão sem o estudo da gramática. Belo Horizonte: Ed. UFMG, 2002.

SENA, Wagner da Rocha. Contribuição ao estudo da norma culta escrita do Português do Brasil. Rio de Janeiro: PUC, 1986 (Mestrado em Letras- Língua Portuguesa). 
SOARES, Magda. Linguagem e escola; uma perspectiva social. 10. ed. São Paulo: Ática, 1993.

. Letrar é mais que alfabetizar. Jornal do Brasil, Rio de Janeiro, 26 nov. 2000. Caderno Educação \& trabalho, p. 1-2. (Entrevista a Eliane Bardanachvili) TRAVAGLIA, Luiz Carlos. Gramática e interação: uma proposta para o ensino de gramática no $1^{\circ}$ e $2^{\circ}$ graus. São Paulo: Cortez, 1996.

Ensino de língua materna - Gramática e texto: alguma diferença? Letras E Artes, Uberlândia, 14(1) 171-179, julho/dezembro, 1997.

VIEIRA, Alice. Prática de ensino de Português: nos domínios da teoria. In: MURRIE, Zuleika de Felice. (Org.) O ensino de Português: do primeiro grau à universidade. 4. ed. São Paulo: Contexto, 1998.

VILELA, José Fernandes. Por que ensinar gramática. In: SEMANA DE ESTUDOS DE LÍnguA PORTuguesA, I, 1993, Belo Horizonte. Belo Horizonte: Departamento de Letras Vernáculas, Faculdade de Letras da UFMG, 1995, v. II, p.35-38.

ZAGURY, Tania. Sem padecer no paraíso: em defesa dos pais ou sobre a tirania dos filhos. 9. ed. Rio de Janeiro: Record, 1994. 